\title{
Evaluation of Academic Library Residency Programs in the United States for Librarians of Color
}

\author{
Angela Boyd, Yolanda Blue, and Suzanne Im*
}

\begin{abstract}
The purpose of this research was to evaluate academic library residency programs that successfully recruit and retain academic librarians of color. This study examines library residencies in the United States and discusses findings of two nationwide surveys. One survey posed questions to residents about the structure of their residencies, aspects residents found most helpful for career advancement, and their thoughts on diversity initiatives. The coordinators were asked many of the same questions as the residents but also about the administrative aspects of their programs. The survey responses reveal a need to provide residents with structured mentoring, along with a sense of belonging and value. Library residency programs can play an integral part in the larger recruitment, retention, and diversity initiatives in the profession.*
\end{abstract}

The purpose of our study was to identify aspects of existing academic library residency programs that are successfully recruiting, mentoring, and retaining new librarians of color. Most of the research in this area and of this scope has not been done in over a decade. Recruitment and retention of qualified librarians, regardless of background, is a pressing concern in all libraries and library systems. The American Library Association (ALA) knew of this concern as far back as 1924, as is demonstrated in the first annual report of the ALA Board of Education for Librarianship (ALA-BEL). The report asserted that, "based on the findings of the Board's survey, a librarian shortage is very real and 'in no way exaggerated."'1 This issue regarding recruitment and retention continues to be the focus of research and much discussion to this day. This is especially relevant today as we realize the changing demographics of the United States and the student populations on our college campuses. Library residency programs can play an integral part in the larger recruitment, retention, and diversity initiatives in the profession.

\footnotetext{
*Angela Boyd is User Experience/Systems Librarian at Cypress College, e-mail: aboyd@cypresscollege.edu; Yolanda Blue is Special Collections Librarian at University of California at Santa Barbara, e-mail: blue@ ucsb.edu; Suzanne Im is Metadata Librarian at the Los Angeles Public Library, e-mail: sim@lapl.org. (C2017 Angela Boyd, Yolanda Blue, and Suzanne Im, Attribution-NonCommercial (http://creativecommons.org/ licenses/by-nc-nd/4.0/) CC BY-NC-ND.
}

**Note: For the purpose of this paper, "America" and "American" refer to the United States of America and its citizens, respectively. 
Residencies, fellowships, and internships are used interchangeably with different frequencies within Library and Information Science (LIS). The investigators could not determine an industry standard terminology for this type of program. However, this article uses the term "residency" as defined by the Association for Library and Information Science Education (ALISE) in the 1992 guidelines published in SPEC Kit 188 by the Association of Research Libraries (ARL). As defined by ALISE, a library residency is "a post-degree work experience designed as an entry-level program for professionals who have recently received a graduate degree." ${ }^{2}$

\section{Literature Review}

\section{Diversity Initiatives in Library and Information Science}

For almost a century now, American libraries have revisited diversity recruitment for a number of reasons. A primary reason was for libraries to better address the needs of the communities in which they served. In 1924, discussions surrounding minority recruitment in libraries were reported to the ALA-BEL. Neely and Peterson referred to this 1924 report in their white paper discussion about the "enthusiasm expressed for the progress on the development of a library school for Negroes (Hampton Institute) because of the need to serve this population in the segregated South." ${ }^{3}$ In addition, Peterson reported that "[i]n 1943, ALA surveyed accredited library schools asking if the schools were permitted to admit Negroes." ${ }^{4}$ Neely and Peterson assumed ALA surveyed accredited library schools at the request of the U.S. Armed Forces. This was an era when Blacks served the United States military in segregated divisions and combat support roles. It was not until 1948, with the passing of Executive Order 9981, that this practice began to change. In addition to the need for Black librarians to serve the Black population in the segregated South, there was a demand for Black librarians to serve on Black military bases. ${ }^{5}$ Today, the reasons for diversity recruitment are also about better addressing the needs of the community, as the demographics of the country continue to change.

ALA estimated in 2012 that only 7 percent of librarians were between the ages of 20 to 29. ALA Demographics Studies reported that as of March 2012, 88.7 percent of librarians identified as White and 80.7 percent as female. ${ }^{6}$ In their 2004 publication "The Diversity Mandate," Adkins and Espinal made a number of key observations about our profession. For example, they comment on how the whiteness of librarianship impacts the public we serve. ${ }^{7}$ There is also a professional impact on librarians of color. Adkins and Espinal noted how the profession professes to be user-centered. They encouraged the profession to diversify to truly be user-centered. Librarians with diverse cultures and language skills are key to providing relevant materials and experiences to our patrons. As Adkins and Espinal pointed out, the educational and other dominant institutions are still geared to white, mainstream cultures. Most Americans are often not taught, nor do they understand, the cultural traditions and knowledge of minority groups. Recruiting from minority groups will result in more knowledgeable librarians to serve these minority communities and enrich librarianship by providing insights not provided by the education industry. ${ }^{8}$ Based on Adkins and Espinal's "The Diversity Mandate," the investigators surmise that, for libraries to continue to be relevant for the growing diverse population in the United States, the workforce must reflect that population.

In "Diversity Counts," Davis and Hall stated, "From 1990-2000, positions within academic libraries declined by $4.4 \%$ for African American librarians." 9 Additionally, "the percentage of credentialed academic librarians from the 2000 U.S. Census and the 2006 ALA membership was 4.5\% African American, 3\% Latino/a, 1.4\% Native American, $2.7 \%$ Asian Pacific Islander, and 89\% White. ${ }^{\prime 10}$ Based on these data, it appears libraries 
as a whole have been slow to recruit librarians who proportionally represent the wider population in a changing America. This does not bode well for culturally sensitive delivery of library services or the future of libraries. Deliberate and strategic action must be taken to recruit, mentor, and retain new librarians from diverse backgrounds to further increase these numbers in the profession.

The investigators posit that academic library residencies can be a powerful tactic in recruitment, retention, and mentorship efforts to develop 21st-century librarians who come from diverse backgrounds. As stated by Dewey and Keally of Hodges Library at the University of Tennessee, Knoxville:

Academic libraries are well qualified to play leadership roles in advancing campus community diversity initiatives because of the inherent commitment to encompassing people and the multitude of ideas reflecting the breadth and depth of the human experience. Libraries also play a central role in the intellectual, social, and cultural life of students, the core campus audience who are at a critical point in their development as productive citizens of the world. ${ }^{11}$

College and university student populations are increasingly diverse, mirroring the rest of the United States. Librarians who understand the unique needs of these students will better serve this population. In recent years, applications from underrepresented minority groups and international students have increased substantially. As discussed by McElroy and Diaz in Residency Programs and Demonstrating Commitment to Diversity, the minority enrollment as of 2010 in the United States has increased by 16 percent among undergraduates and by 17 percent among graduate students since 1990. Furthermore, McElroy and Diaz noted that the number of minority faculty in academic positions has more than doubled from 1990 to $2010 .{ }^{12}$ As reported by Colby and Ortman in the publication Projections of the Size and Composition of the U.S. Population: 2014 to 2060, "by 2044, more than half of all Americans are projected to belong to a minority group... and by 2060, nearly one in five of the nation's total population is projected to be foreign born."13

McElroy and Diaz's findings contrast with what ALISE reported in 2011 regarding diversity in the LIS graduate student population. According to ALISE, out of the 8,227 ALA- accredited library science master's degrees awarded in the United States in 2010 to 2011, only 2.96 percent went to Hispanics (244), 3.37 percent were awarded to African Americans (278), 3.26 percent to Asian/Pacific Islanders (269), and 0.48 percent to American Indians (40). The numbers may not be wholly accurate, as 11.53 percent (949) refused to state any race or ethnicity. ${ }^{14}$ However, the numbers still highlight the importance of recruiting and retaining a diverse library workforce. As suggested by Hankins, Saunders, and Situ, the investigators encourage academic libraries to view diversity initiatives and residency programs as complementary entities that should partner easily: “The combination of diversity initiatives and residency programs commits the entire campus and its surrounding community to work toward a common goal that can cement ties and bridge cultural differences." 15

\section{Organizational Effectiveness}

The bulk of research from the business world suggests that diversity leads to positive organizational outcomes. Herring found that "diversity is associated with increased sales revenue, more customers, greater market share, and greater relative profits." ${ }^{16}$ Furthermore, according to Cox and Blake, managing cultural diversity contributes to "cost, attraction of human resources, marketing success, creativity and innovation, problem-solving quality, and organizational flexibility." ${ }^{17}$ Robinson and Dechant men- 
tioned diversity as also leading to organizational innovation. Although diverse groups initially encounter more conflict in working together and trying to establish priorities, they ultimately outperform homogenous groups in identifying issues and providing alternative solutions. This is because conflict forces diverse groups to look beyond easy answers that occur in like-minded groups. ${ }^{18}$ According to Phillips, Liljenquist, and Neale, diversity triggers more careful analysis of the information presented in a way that does not happen with homogenous groups. The fact that there is diversity in a group creates an awkwardness that pushes group members to diffuse the tension. This leads to better group problem solving. ${ }^{19}$ Phillips andher coauthors have demonstrated that, while homogenous groups feel more confident in their performance and group interactions, it is the diverse groups that are more successful in completing their tasks. ${ }^{20}$

Using diverse groups is a practice that lends itself easily to the LIS field and gives the profession more of a reason to recruit librarians from diverse backgrounds. Dewey and Keally state:

[t]hese librarians bring new perspectives, ideas, and training to jump start the academic library's entry into the twenty-first-century world of global scholarship, learning methods, and high-tech means of communication. Next steps for advancing recruitment of librarians with diverse backgrounds includes [sic] focused programmatic initiatives at the international, national, local[,] and regional level within an institution and its library's overall diversity plan. $^{21}$

In addition to the career development opportunities for the residents, Brewer stated that "career-span diversity also enhances organizational effectiveness through professional and career development." ${ }^{22}$ When individuals at different points in their careers work, collaborate, and learn from one another, the organization is more dynamic. The establishment of residency programs geared toward diversity results in diversity outcomes. Brewer also pointed out that long-standing programs "publicly demonstrate a sustained commitment to diversity over time, as well as organizational adeptness in managing diversity." 23

\section{Overview of the History of Librarian Training in America}

In the early 1900s, library training programs were viewed as a means to introduce early-career librarians to successful work experiences. Lynch described a movement at that time to implement a more comprehensive librarian training. During this time, there was increased study of library science education, library internships, and library trainings. Around 1915, the Carnegie Corporation of New York began receiving many requests for grants to establish training programs for librarians. In response to these requests, the corporation invited Alvin Saunders Johnson "to inquire into library schools and the adequacy of the output of trained librarians." ${ }^{24}$ Johnson's report offered a damaging assessment of the programs of study at the thirteen library schools then operating. Although the corporation rejected most of Johnson's recommendations, they did pay attention to the many issues he mentioned in his report related to training possibilities for the library profession. ${ }^{25}$ Concerned by Johnson's reports of the low quality of library staff, the trustees of the corporation hired Charles C. Williamson to conduct a major survey of library education from 1919 to $1921 .^{26}$ The Williamson Report, published in 1923, recommended a second year of advanced study that would be similar to the types of internships used in medicine. The second year would be complementary with the first year of job experience, allowing the intern to gain skills in a specialized field. ${ }^{27}$ In 1926, with the establishment of the Graduate Library School at the University of Chicago, librarianship moved from a vocation to a profession. 
This offered a professional school for librarians that was analogous to Harvard Law School and the John Hopkins Medical School. The Graduate Library School in Chicago took library trainings out of libraries and into a graduate or professional school. The Master's in Library Science (MLS) was created, and, due to the formalization of the program at the Graduate Library School, it became widely accepted as the credential for professional librarians. ${ }^{28}$

In 1937, Francis R. St. John also began investigating library internships at the request of ALA-BEL. He recommended the formation of a special committee formed by ALA-BEL, representatives from library schools, and participating libraries. This committee would set minimum requirements for an internship training course, approve libraries as training agencies, and select library school graduates on the basis of outstanding ability, personal qualifications, and leadership potential. His recommendations resulted in minimum requirements, such as a twelve-month period at a minimum wage with two months of training in reference, cataloging, circulation, and administration. Any time remaining of the twelve months would be spent in any field of most interest to the intern. Minimum wage would depend on the cost of living near the host institution. ${ }^{29}$

In the late 1930s, several institutions began "internships" that worked similarly to the residencies as we know them today. St. John's recommendations were put into practice under the auspices of the Tennessee Valley Authority (TVA), which was established by Congress in 1933 to address a wide range of environmental, economic, and technological issues. TVA worked with ALA-BEL to recruit and monitor internship programs implemented at the University of Illinois (1938) and the University of North Carolina (1939). These institutions put into practice some of St. John's recommendations, including an orientation followed by three training periods. Each training period provided emphasis on a different area of librarianship and one month of paid vacation. A subsistence-level salary was offered. The intern's direct supervisor submitted monthly progress reports, and the intern also wrote critical reports at three-month intervals. This experimental internship program came to an end due to manpower shortages during World War II. ${ }^{30}$

According to Brewer, two of the longest running programs in the United States began a decade later as the Library of Congress (1949) and the National Library of Medicine (1957) developed a one-year training program that included rotating assignments with professional salaries. ${ }^{31}$ Around 1977, the Association of American Library Schools (AALS), a predecessor of ALISE, and the Association of College and Research Libraries (ACRL) Personnel Administrators and Staff Development Officers Discussion Group proposed that each major research university create at least one permanent entry-level intern position. The positions would be structured in a way that is most advantageous to the host institution, while keeping in mind the training aspect for the intern. ${ }^{32}$ The positions proposed would follow the Library of Congress model whereby the individual rotates through a variety of areas and activities within the library, so that the intern gains an understanding of the overall workings of a library. ${ }^{33}$

Lanier and Henderson explored a later proposal that emerged from an ACRL and AALS partnership in 1983. The two organizations drafted a statement of "Recommended Guidelines for a Post-Masters Internship Program" that continue to influence programs today. These guidelines expected host institutions to report diversity efforts, offer residencies that were a minimum of one year in length with the possibility of a one-year extension, not consider the residency as a probationary employment period, be large enough to manage residencies effectively, include an educational component for residents, and offer residents salaries that were equivalent to starting salaries for other beginning professionals. ${ }^{34}$ 


\section{Affirmative Action and Residency Programs}

Starting in the 1980s, library residency programs were shaped by affirmative action policies that aimed to increase the number of librarians of color in academic libraries. The Oxford English Dictionary defines "affirmative action" as "U.S. action taken to affirm an established policy; spec. active measures taken by an employer, college, etc., to provide opportunities for members of minority groups, women, or other people regarded as having suffered from discrimination." ${ }^{35}$ The term "affirmative action" was coined by President John F. Kennedy on March 6, 1961, and expanded by President Lyndon B. Johnson. Throughout this time period, the provisions were amended to ensure that Americans received equal opportunities with regard to education and employment, irrespective of their gender, race, creed, color, religion, or national origin. ${ }^{36}$

However, as pointed out by Boissé and Dowell in "Increasing Minority Librarians in Academic Research Libraries," in spite of these efforts, in 1986 only 9.8 percent of all positions in ARL libraries were filled by minority librarians. ${ }^{37}$ Ultimately, by the early 2000s there was an increased backlash against affirmative action, resulting in bans in eight states (see figure 1). ${ }^{38}$

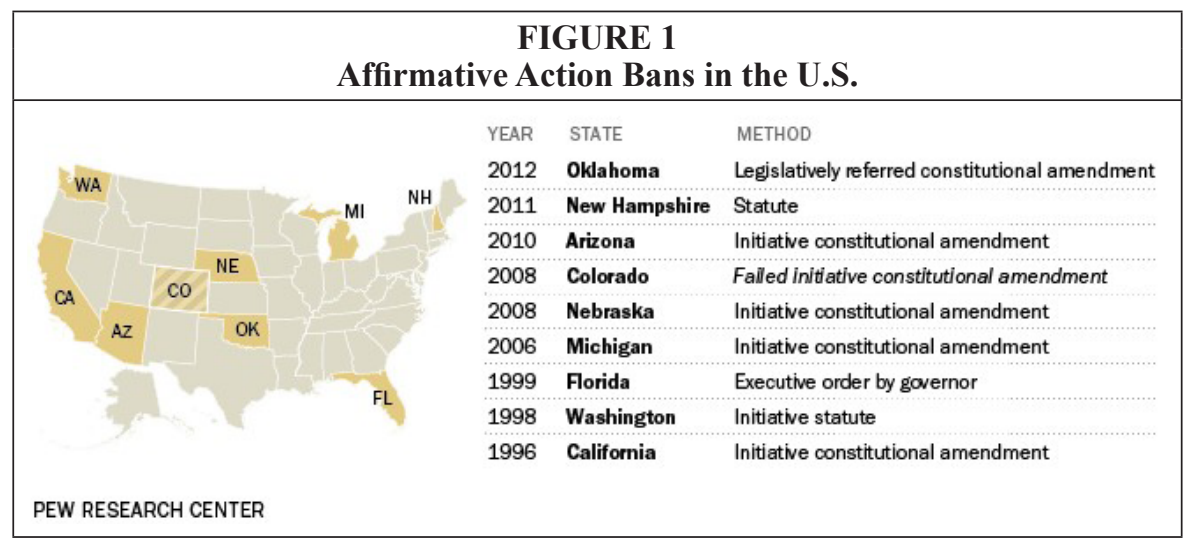

The bans prohibited these eight state governmental institutions from considering race, sex, or ethnicity, specifically in the areas of public employment, public contracting, and public education, including public universities. As a result, many residency programs transitioned to "neutral" job titles while still recruiting for diversity, particularly in the eight states where affirmative action was banned. In addition, the authors surmise that a number of residencies may have shut down in these eight states because of this ban.

There are a number of residency programs that have served as models for their innovative successes. Brewer mentioned that the University of Delaware (1984) and the University of California at Santa Barbara (UCSB) (1985) were the first institutions to implement library residency programs with minority recruitment as a programmatic focus in the mid-1980s. ${ }^{39}$ Due to the ban on affirmative action in California, the UCSB residency program continues, but it ceased to be used as a minority recruitment tool. One program that has been well documented from the start, continues to this day, and has maintained its diversity focus is The Ohio State University (OSU) Mary P. Key Diversity Residency Program. Begun in 1961, the OSU program emulated the Library of Congress residency program. It was established to give new library school graduates a broad overview of academic librarianship at a large research university. However, financial issues in 1973 shuttered the program. ${ }^{40}$ In 1989, OSU reinstituted the residency program as a minority recruitment initiative that continues to this day. 
OSU has made a number of changes to the program: for example, extending it from a one-year to a two-year appointment, adding a predetermined focus, and recruiting residents who have some experience or an interest in that area. ${ }^{41}$

While many residency programs that exist today are focused on diversity, there is a resurgence of residencies aimed not at recruiting underrepresented or minority librarians but at mentoring librarians new to the field based on merit and the specific areas of need in a library. This is a mutually beneficial arrangement, as many libraries look to "fill in gaps" with new graduates who presumably have obtained knowledge and skills in library school relevant to the latest trends and technological advances in the profession.

Despite all of the research and the interest in these types of programs over the years, as of this writing there were only thirty-two known active residencies in academic libraries. In addition, there were four in special libraries and two in public libraries across the United States, according to the ACRL Residency Interest Group website. ${ }^{42}$ As Brewer noted, these low numbers may be the result of changes in the economy, institutional leadership, and organizational priorities, all of which affect the availability, numbers, and longevity of these programs. ${ }^{43}$ In addition, Dougherty and Lougee mentioned declining support of libraries as a possible cause. ${ }^{44}$

\section{Formal Mentoring and Group Camaraderie}

Many newly minted librarians are unfamiliar with the organizational structure and culture of an academic library. According to William Black and Joan Leysen, for entry-level librarians to succeed in the transition from library school to the academic environment, effective socialization is a critical factor. ${ }^{45}$ Furthermore, it is important for new librarians to acclimate to the academic culture. For a new librarian, understanding the library culture is a vital component to succeeding in a residency program. ${ }^{46}$

Sannwald believed that an introduction to organizational culture provides several benefits for the individuals. Those benefits include organizational identity, collective commitment to the organization, positive reinforcement in the work environment, and the ability of people to make sense of the organization. ${ }^{47}$ For the residents to fully acclimate to the library's organization, structured mentoring is the most optimal. According to Taylor, a former resident at the University of South Florida Tampa Library, "the mentor becomes a 'buddy' who, among many functions[,] accompanies the resident to conferences[,] acts as a liaison within the library[,] helps to foment peer relationships[,] assists in the development of assignments[,] and identifies the resident's career goals." 48

This structured type of mentor-mentee relationship cultivates the residents' socialization into the organizational culture. It also symbolizes the buy-in of the library's commitment to facilitating the residents' successful achievement of career goals. Furthermore, Taylor stressed that the mentor's structured involvement directly impacts the growth potential of each resident. ${ }^{49}$ Given the limited number of underrepresented librarians in the profession, mentors help to create a bridge between graduate education and the workforce.

Solo library residents can find their residencies to be overwhelming and isolating experiences, especially in the case of diversity library residents. Cohorts can be a solution to this dilemma through the provision of group mentoring. Johnson discovered that small group mentoring imparts stress-reduction benefits with the advantages of individual mentoring for a cohort of newly qualified professionals. ${ }^{50}$ In the group-mentoring arrangement, the roles and responsibilities of mentoring are shared by the group's leaders and the participants and implemented over time. 
Successful group mentoring enables the participants to serve as peer mentors to each other, serving the much-needed function of mutually supporting and encouraging each other. ${ }^{51}$

\section{Structure of Residency Programs}

The structure of a residency impacts the success of the program. As discussed by Alston in Minerva's First Born: My Experiences as UNCG's First Diversity Resident Librarian, libraries may want to structure their programs tailored to the type of resident recruited. He emphasizes that "new librarians with limited library backgrounds may lack perspective on the range of experience offered by various library departments." This may cause a resident to overlook a serendipitous career opportunity. ${ }^{52}$ Thus, libraries should structure their programs to facilitate the residents' opportunity to gain the broadest professional knowledge and skill set that will best prepare them for academic careers.

The length of the residency is another crucial component of a program's structure. It is now common for many entry-level positions in academic libraries to require two to five years of professional experience. Especially in times of economic hardship and the competitive job market, residents will need time to develop professional skills that will facilitate successful employment opportunities. Residents also need time to acclimate to a new library and to discover their passions. In 2001, Brewer and Winston conducted a survey of deans, directors, and program coordinators from internship/ residency programs in academic libraries. The findings reported "all deans and directors noted that continuation in a program for a second year was very important." 53

\section{Rationale for Research}

The investigators found limited studies conducted on diversity residencies in academic libraries. Updated information regarding the implementation of library diversity residency programs and the identification of successful outcomes of recruitment and retention in the profession is needed. The 2010 U.S. Census data show a marked increase in diverse populations in communities across the United States. ${ }^{54}$ However, academic libraries lack a substantially diverse workforce to serve these communities. Our research seeks to identify aspects of academic library residency programs that successfully recruit and retain academic librarians of color.

Although LIS leaders have acknowledged that staffing libraries for diversity would benefit the whole community, the demographics in academic libraries have not shifted significantly. LIS leaders and scholars should have a vision of what impact libraries can have when the profession embraces diversity. To attain that impact, library professionals and administrators must develop the skills and commitment to act on that vision. Two successive ALA presidents have expressed concern over diversity issues in the profession. In the publication Diversity Counts, 2012 to 2013 ALA President Sullivan stated, "although the findings show some improvement in the diversity of the library workforce, we clearly have a long way to go." She pointed out that "we must do the research necessary to discover effective ways to increase the numbers. This is a matter of urgency for all of us." ${ }^{55}$ Sullivan's successor, 2013-2014 ALA President Stripling, also recognized that "[m]embers of our communities and profession continue to face inequity and discrimination." 56

Gerhard and Boydston found that, as far back as January 1990, ACRL's Task Force on Recruitment of Underrepresented Minorities were working to recruit and retain minority librarians. The task force identified three causes that contributed to low recruitment and retention of minority academic librarians: lack of institutional commitment to change and accountability, personal and institutional racism, and barriers to advancement and retention. ${ }^{57}$ 
According to LIS researchers Kim and Sin, the top five strategies for recruitment were: (1) assistantship/scholarship/financial aid; (2) ethnic diversity in faculty; (3) role models from ethnic groups; (4) presence of faculty/staff of color in the recruitment process; and (5) opportunities to work in LIS-related fields. ${ }^{58}$ Strategies suggested by more than half of the participants in their study also mirror in many ways the top five strategies suggested by Kim and Sin: (1) assistantship/scholarship/financial aid; (2) opportunities to work part-time in LIS-related fields; (3) faculty/staff sensitive to the needs of students of color; (4) mentoring programs; and (5) effective academic/ career advising. ${ }^{59}$

\section{Methodology}

Since there were numerous residency coordinators and residents who were based at various institutions across the United States, the investigators decided it would be best to conduct an online survey to reach and collect the largest sample possible. A review of the literature allowed us to determine the questions to include in the survey, particularly Brewer and Winston's 2001 evaluation of academic residency programs. The investigators further consulted three residents, two personnel/human resources administrators, an academic library director, and two social science researchers to evaluate the questions to be asked in the survey, as well as to assess the survey's length, lucidity, and ease of response. Iterative drafts of the survey were pretested with the aforementioned individuals consulted. The questionnaire was designed to identify aspects of academic library residency programs that successfully recruit and retain academic librarians of color.

The investigators searched online for active and inactive academic library residency programs across the United States to approach for this study. The investigators had some difficulty identifying these programs, as well as current and former residents, as there was no centralized database that listed all such programs. Many of the inactive programs and some of the current programs did not keep up-to-date websites, if they had any web presence at all.

Ultimately, fifty-seven active and inactive programs in academic libraries were identified (see appendix C). Current and former residents were recruited in a variety of ways. The investigators requested that coordinators forward a call for participation to current and former residents. Recruitment of residents also relied heavily upon listservs like the one provided by the ACRL Residency Interest Group. The investigators also reached out directly to current and former residents.

The UCSB Social Science Survey Center (SSSC) set up two short, secure online questionnaires with SSL and 128-bit encryption. In the spring of 2013, the SSSC e-mailed surveys to coordinators and current and former residents of the programs. The deadline for responding to the survey was March 31, 2013. For the coordinators, each survey contained a questionnaire for the coordinator to complete. Coordinators were asked to complete the survey even if their programs were inactive.

The SSSC mailed fifty-seven coordinators three times, at two-week intervals. Similarly, three staggered e-mails were sent out to recruit current and former residents. All participants were informed that their participation was voluntary. Any identifying information gathered was separated from responses to protect the privacy of the participants. The investigators informed each participant that the study had been approved by UCSB's Institutional Review Board (IRB) and presented them with a consent form that described thoroughly the study and their rights as human research subjects. The participants were told that it would take approximately twenty to thirty minutes to complete the survey and that the results would be kept anonymous. The questionnaire included multiple choice and open-ended questions. 
Coordinators were asked about the structure, mission and/or goals, and activities of their library residency program; some details about their library and budgets; aspects of their program they found to be most beneficial to new librarians; aspects of the types of mentoring offered to residents; and improvements they would like to implement. Current and former residents were asked many of the same questions, but also about diversity initiatives they were involved in, thoughts about their experience as a resident, aspects of their program that were most beneficial, and whether they worked with the program coordinator to improve the program for future participants. There was a 49.12 percent response rate from residency coordinators, with 28 complete surveys and 22 incomplete surveys. There were 68 complete responses and 112 incomplete responses from current and former residents. While this study was originally designed to evaluate academic library residency experiences of librarians of color, we did not screen out participants by race, ethnicity, gender, or other demographics. Because we did not screen it, the participant pool included 39.4 percent of our resident respondents who self-identified as White. The researchers decided to include their responses in the report and analysis.

\section{Results}

The overall results from the survey of coordinators and residents are organized based on our aim to determine the aspects of the effectiveness of the residencies. We examined the general structure of residencies, such as the number of residents in a cohort, efforts to promote diversity, and professional skills. We also examined activities of the residencies, such as whether formal or informal mentoring was offered, the activities the residents participated in, as well as residents' and coordinators' comments regarding improvements to the programs.

\section{Organization and Effectiveness of Residencies}

Residency programs in the sample were established as far back as 1981. Three residency programs were established each in 1998, 2000, 2010, and 2012. This represents the largest number established in any year reported by coordinators. Two $(6.9 \%)$ residencies were each established in 1989, 1999, and 2008. Residency programs were also established at a rate of one per year (3.4\%) in 1981, 1983 to 1985, 1987, 1992, 1996, and 2001. Coordinators similarly reported on how long the residency program had been active.

Slightly more than half $(n=15)$ of the programs in the sample had been active for five years or less (2006 to 2012). One in five $(20.6 \%$; $=6$ ) had been active for eleven to fifteen years (1996 to 2000). This corresponds well with the coordinators reporting that most residencies were established in 1998, 2000, 2010, and 2012. Two coordinators each $(6.9 \%)$ reported that their programs were active for 6 to 10 years, 16 to 20 years, 21 to 25 years, or 28 to 29 years.

After determining which residencies were currently hosting residents, the investigators further inquired regarding whether these residencies were also actively recruiting and/or planning for the next resident or cohort. More than half $(59.4 \% ; n=19)$ of the program coordinators were actively recruiting, while 40.6 percent $(n=13)$ were not. Of those no longer recruiting, 61.5 percent $(n=8)$ stated that lack of financial support was the reason. Other reasons reported by 15.4 percent $(n=2)$ of the sample included bans on affirmative action and lack of administrative support, while 7.7 percent $(n=$ 1) mentioned lack of available librarians to train or mentor residents. Nearly one in three $(30.8 \% ; n=4)$ said there were other reasons than those listed in the survey but did not specify.

There were many more coordinators reporting their librarians had faculty status than not, with 62.5 percent $(n=20)$ stating they did have faculty status, while 37.5 percent $(n=12)$ did not. 
Coordinators reported that the vast majority of the residency programs were two years in length. More than four out of five $(81.7 \% ; n=27)$ were two years in length; 9.7 percent $(n=3)$ were one year in length; and 3.2 percent $(n=1)$ were less than one year in length. Nearly all $(96.7 \% ; n=29)$ reported that their residencies were full-time positions, while 3.3 percent $(n=1)$ were part-time. The hourly pay rates of residents and other regular librarians' entry-level positions were very similar, although residents were paid slightly less. Most residents were paid at the $\$ 19$ to $\$ 21.50$ an hour rate. This roughly translates to $\$ 39,520$ to $\$ 44,720$ per year. Meanwhile, most regular librarians earned slightly more at $\$ 44,720$ to $\$ 49,920$ per year. Aside from the oneunpaid residency, every residency paid above $\$ 24,960$ per year or $\$ 12$ an hour (see table 1).

\begin{tabular}{|l|c|c|c|c|}
\hline \multicolumn{5}{|c|}{ TABLE 1 } \\
\multicolumn{5}{|c|}{ Hourly Pay Rate of Residents and Regular Librarians as Reported by } \\
Coordinators (N=22)
\end{tabular}

Nearly one-third $(32.5 \% ; n=25)$ of the resident respondents were currently in a residency program. Former residents comprised 67.5 percent $(n=52)$ of the respondents. Seventy-one current and former residents shared the name of the institution that hosted their residencies. Forty-five colleges and universities were represented in this pool. Just over 1 in $10(11.3 \% ; n=8)$ of the respondents were residents at the University of Alberta. Only 9.9 percent $(n=7)$ listed the University of Michigan as the host of the residencies. Wayne State University was selected by 7 percent of the respondents ( $\mathrm{n}=$ 5). Syracuse University, the University of Illinois at Chicago, the University of Houston, and the University of North Carolina at Greensboro each had 3 respondents (4.2\%). Kansas State University, North Carolina State University, The Ohio State University, Santa Barbara City College, SUNY Buffalo, the University of Arizona, the University of California at Santa Barbara, and the University of Delaware each had $2(2.8 \%)$ respondents. Finally, Auburn University, Central Washington University, College of Wooster, Cornell University, Indiana University, Loyola Marymount University, Library 
of Congress, Marquette University, Miami University, National Library of Medicine, OCLC, Pratt Institute, Queens College CUNY, Towson University, the University of Arkansas, the University of California, the University of California at San Diego, the University of Colorado at Denver, the University of Illinois at Urbana-Champaign, the University of Louisville, the University of Notre Dame, the University of Pennsylvania, the University of South Florida, the University of Southern California, the University of West Georgia, Vanderbilt University, Western Washington University, and Yale University were selected by $1(1.4 \%)$ resident each.

Resident respondents' ages ranged from 24 to 59 years. A total of $19(29 \%)$ were 24 to 29. Just over one-third $(36 \% ; n=24)$ were thirty to thirty-nine. One in five $(20 \% ; n=13)$ were 40 to 49 , and 15 percent $(n=10)$ were 50 to 59 . Similar to the demographics in our profession, 84.8 percent $(n=56)$ of respondents identified as female, while 15.2 percent $(n$ $=10)$ of respondents identified as male. A total of $26(39.4 \%)$ of respondents were white; $7.6 \%(n=5)$ were Spanish, Hispanic, or Latino/a; $19.7 \%(n=13)$ were African American; $22.7 \%(n=15)$ were Asian American; $6.1 \%(n=4)$ were biracial or multiracial; and $1.5 \%$ $(\mathrm{n}=1)$ were Native Hawaiian or other Pacific Islander, and Native American or Alaskan Native. One resident (1.5\%) preferred the term "Black" rather than "African American." However, for the purposes of this paper, this person has been grouped with the thirteen African Americans for a total of fourteen. The categories used by the researchers were defined by the U.S. Bureau of the Census (BOC) in accordance with guidelines provided by the U.S. Office of Management and Budget. ${ }^{60}$ While overall the number of women was overwhelmingly higher than the number of men, it was particularly striking with regard to the Spanish, Hispanic, or Latino/a respondents. Within this Spanish, Hispanic, or Latino/a population, 100 percent $(n=5)$ of the respondents were female.

Going through the decades, 6.7 percent $(n=5)$ of the respondents completed their residencies in 1980 to $1989,13.5 \%(n=10)$ in 1990 to $1999,30 \%(n=21)$ in 2000 to 2009, and $54 \%(n=38)$ in 2010 to 2015 . Nearly half $(46.8 \% ; n=59)$ of the residents completed or planned to complete their residency in the 2010s. The residents who completed their

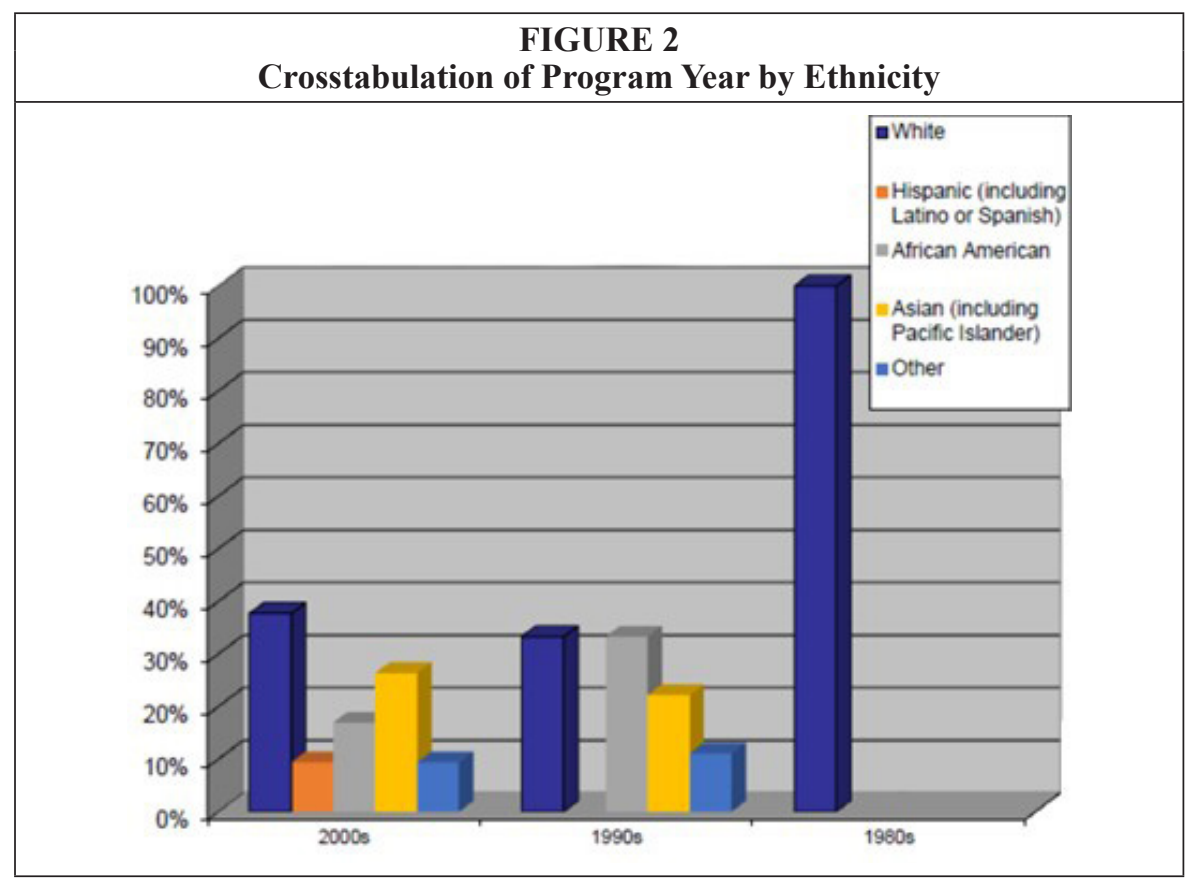


programs in the 1990s or 2000s were substantially more diverse than those who finished in the 1980s. Non-Hispanic (including Latino/a or Spanish) residents were represented in the sample prior to the 2000s. The percentage of African American residents was higher in the 1990s than in the 2000s (see figure 2).

The vast majority of the resident respondents participated in a two-year residency, with 61.8 percent $(n=42)$ reporting as such. A total of $15(22.1 \%)$ were in a one-year program, and 11.8 percent $(n=8)$ reported that their program was less than a year. A tiny minority, 4.4 percent $(n=3)$, was in a three-year program. More than 4 out of 5 $(82.6 \% ; n=57)$ were considered full-time employees during their residency, while 17.4 percent $(n=12)$ were considered part-time.

Fully 87.13 percent $(n=88)$ of all resident respondents indicated that their current department affiliation was library-related, demonstrating that residency programs have been successful in retaining early-career librarians within the profession. Only $1(0.99 \%)$ reported that a sample of other departments mentioned include a federal grant-making agency, a health research team, and the Centennial Campus Research Service (see table 2). The single most frequently held position title chosen by 17.5 percent $(n=18)$ of the sample was reference librarian. A total of $15(14.6 \%)$ indicated that their position title was instruction librarian, while 9.7 percent $(n=10)$ were currently in a residency program. Most, 37.9 percent $(n=39)$, indicated they held a title other than what was given as a choice in the survey. Examples of these included titles such as Associate Librarian; Copyright \& Policy Librarian; Manager, Library Human Resources; PhD student; and Project Manager (Vendor).

\begin{tabular}{|l|c|c|}
\hline \multicolumn{3}{|c|}{ TABLE 2 } \\
Current Departmental Affiliation As Reported by Residents (N=101) \\
\hline Departments & n & \% \\
\hline Reference and Instruction/Public Service & 35 & $34.65 \%$ \\
\hline Information Technology/Systems/Web Services/Engineering & 10 & $9.9 \%$ \\
\hline Technical Services & 8 & $7.92 \%$ \\
\hline Outreach, Special Collections/Archives & 7 & $6.93 \%$ \\
\hline Digital Image Collections & 5 & $4.95 \%$ \\
\hline Data Curation & 4 & $3.96 \%$ \\
\hline Access Services, Administration, Digital Preservation & 3 & $2.97 \%$ \\
\hline Human Resources & 2 & $1.97 \%$ \\
\hline $\begin{array}{l}\text { Acquisitions, Art Library, Branch Library, Centennial Campus Research } \\
\text { Services, Community Services, Federal Grant Making Agency, Health } \\
\text { Research Team, Graduate School Student, Multimedia Design, None, } \\
\text { Publishing, School Library, Textiles, Undergraduate Services }\end{array}$ & 1 & $0.99 \%$ \\
\hline Total & & \\
\hline & $\mathbf{1 0 1}$ & $\mathbf{1 0 0 \%}$ \\
\hline
\end{tabular}

The residents reported earning more than what the coordinators reported. Nearly 1 in $5(17.5 \%$; $n=11)$ reported earning $\$ 21.50$ to $\$ 24$ an hour, while 20.3 percent $(n=12)$ reported that their regular librarian counterparts were paid at the rate of $\$ 19$ to $\$ 21.50$ an hour. This roughly translates to $\$ 39,520$ to $\$ 44,720$ per year, while the residents were paid roughly $\$ 44,720$ to $\$ 49,920$. Many more residents than coordinators reported being paid less than $\$ 10$ an hour. A total of $3(4.8 \%)$ reported their residencies were unpaid, while 7.9 percent $(n=5)$ were paid less than $\$ 10$ an hour (see table 3). 


\begin{tabular}{|l|c|c|c|c|}
\hline \multicolumn{5}{|c|}{ TABLE 3 } \\
\multicolumn{2}{|c|}{ Pourly Pay Rate of Residents and Regular Librarians as Reported by } \\
Residents (N=63)
\end{tabular}

\section{Influence of Diversity-Selection Process}

In explaining how diversity is weighted in the selection of candidates, one residency program coordinator stated, "Since our residency is a diversity initiative (defined as racial/ethnic diversity), diversity is strongly weighted in the selection of candidates after initial screening for minimum qualifications." Another coordinator stated, "[W]e understand this could be a risk issue, but are willing to take the risk." Two programs took a more racially ambiguous approach and "look[ed] for past experience or leadership promoting diversity issues or programs," or required the "[a]bility and willingness to work with diverse groups both on the staff and within the patron community."

While the programs were mixed in their usage of diversity in their hiring, the coordinators had a very clear sense of how they defined diversity. As expected, 100 percent $(n=21)$ of coordinators considered underrepresented people of different races or cultures in their definition, while 23.7 percent $(n=5)$ of the coordinators included physical abilities in their definition. A total of $3(14.3 \%)$ included specialized skills not currently at their institutions. Nearly 1 in $10(9.5 \% ; n=2)$ took into consideration socioeconomic status, gender, and sexual orientation. Even fewer, 4.8 percent $(n=1)$, considered age, geography, language, and life experience. Surprisingly, although the Equal Employment Opportunity Commission (EEOC) lists religion as a protected category, no one in the sample considered it in their definition of diversity for their residency programs.

Residents were asked about the type of diversity effort they were involved in. Nearly 1 in $5(19.4 \% ; n=9)$ of the residents reported presentations as their preferred method of promoting diversity in LIS. Some of the other efforts included committee work, grant participation, and recruitment.

Of particular note were the findings regarding resident involvement among librarians of color in promoting diversity in academic libraries. African American residents 
were overwhelmingly much more involved in diversity efforts than other groups. Nine out of $10(90 \% ; n=13)$ of African American residents stated they had been involved in efforts to promote diversity, including mentoring, career coaching, financial assistance, presentations, panel discussions, and other means. Six out of $10(60 \% ; n=3)$ of Spanish, Hispanic, or Latino/a residents reported involvement in efforts to promote diversity, including mentoring, presentations, and other means, while 63.7 percent $(n=9)$ of Asian American residents reported involvement in promoting diversity in academic librarianship, including presentations, panel discussions, and other means. Other means among all groups included: "[g]rant participation," "[r]ecruitment," and "[c]ommittee work." For some groups there were "[t]oo many to specify," and another group "[r]an an undergraduate retention [and] recruitment program and served on the Library's diversity committee" (see table 4).

\begin{tabular}{|l|c|c|}
\hline \multicolumn{3}{|c|}{ TABLE } \\
Diversity Effort As Reported by Residents (N=36) \\
\hline Type of Diversity Effort & n & \% \\
\hline No & 12 & $33.3 \%$ \\
\hline Other & 9 & $25 \%$ \\
\hline Panel Discussions, Presentations & 4 & $11.1 \%$ \\
\hline Mentoring & 3 & $8.3 \%$ \\
\hline Career Coaching, Financial Assistance & 2 & $5.6 \%$ \\
\hline Total & $\mathbf{3 6}$ & $\mathbf{1 0 0 \%}$ \\
\hline
\end{tabular}

The library funded the majority of the residencies in the sample. Roughly 4 out of 5 (80.8\%; $\mathrm{n}=21$ ) of the coordinators reported that their libraries funded their residency programs. Of those supported by libraries, state allocations and tuition funded 70.6 percent $(n=12)$ of the programs. One reported their library's operating budget funded their program. Grants funded 11.5 percent $(n=3)$ of the programs, while foundations funded 3.7 percent $(n=1)$. Nearly 1 out of $5(19.2 \% ; n=5)$ offered examples of other types of funding; other sources of funding included Academic Affairs, central funding from the university, the Provost's office, and the university librarian's discretionary funds.

The library largely predetermined the residents' assignments. More than half ( $51.9 \%$; $\mathrm{n}=14$ ) of the programs preselected the assigned department(s) for the residents. Nearly 1 in $5(18.5 \%$; $n=5)$ either allowed their residents to choose their assigned department(s) according to library needs or allowed the residents to negotiate (an) assignment(s) with the library. Roughly 1 in $10(11.1 \% ; n=3)$ allowed the residents to choose their assigned department(s) according to their own interests, regardless of the needs of the library. Half $(n=14)$ of the programs offered their residents a standing assignment with a focus. Nearly one-third $(31.4 \% ; \mathrm{n}=6)$ offered rotations in various departments. More than one-quarter $(28.6 \% ; n=8)$ offered other, more flexible structures, such as "[h]alftime in home department[,] halftime on strategic initiative" and "[r]otations to a range of libraries[,] as well as rotations throughout different library departments at the home institution."

Residents were assigned to a variety of departments during their tenure. The reference and instruction department was the most represented, with 69.2 percent $(n=18)$ reporting their residents were assigned to this department for part of the, if not the entire, residency. Technical services was also represented strongly by 34.6 percent $(n=9)$ of the respondents. Nearly 1 in $5(19.2 \%$; $=5)$ reported spending time working with outreach, 
data curation, and digital image collections. Finally, 11.5 percent $(n=3)$ got experience with access services and digital preservation. Other departments mentioned include: "Any or all of the above mentioned in the table or any other department in the library (sometimes dependent on the interests of the resident)," "[a]rchives and special collections," "[s]cholarly communication," "[m]usic library," and "[i]nstructional design."

Professional development funds for attendance at conferences, trainings, webinars, and workshops were offered by 92.9 percent $(n=26)$ of the programs. Nearly 1 in 5 $(19.2 \% ; n=5)$ supported continuing education in the form of advanced degrees, while 15.4 percent $(n=4)$ provided funds for research and for memberships in professional organizations. A total of $2(7.7 \%)$ of the coordinators clarified that the funds their programs provided had no stipulations attached to them; instead, the residents determined how to best spend the monies. One (3.8\%) of the coordinators mentioned that his or her program also supported presentations and writing. Another coordinator $(3.8 \%$; $\mathrm{n}=1$ ) said that, in addition to the annual professional development allowance given to all librarians, the resident received an extra $\$ 2,000$. Two $(7.7 \%)$ of the programs did not offer professional development funds of any kind.

More than half $(57.4 \% ; n=35)$ of the residents' assignments were predominantly structured in standing assignments with a focus, while 29.5 percent $(n=18)$ had rotations in various departments. A total of 8 (13.1\%) mentioned having: "[t]wo standing assignments" or a "[s]tanding assignment in one department while rotating through numerous others." One of these eight residents mentioned that he or she "got to choose which departments and for how long first," and another of the eight described the experience as "[s]ix months [of] rotations in various departments [and the] second half were in two standing assignments with focus."

A total of $4(15.4 \%)$ resident respondents were provided no professional development funds at all during their residencies; however, the majority of the respondents did receive professional development funds. Of those, 78.3 percent $(n=54)$ were provided funds for conference attendance; 60.9 percent $(n=42)$ received funds for training, webinars, and workshops; 5.8 percent $(n=4)$ were given funds for pursuing advanced degrees and/or performing research; and 21.7 percent $(n=15)$ had their professional organization membership dues covered. Only 4.3 percent $(n=8)$ received funds for mentoring and network building, and 1.4 percent $(n=1)$ noted that the funds allowed for maximum flexibility and could be used at the resident's discretion.

Almost all of the residents were encouraged to participate in professional development activities during their residencies. Nearly all $(93.8 \%, n=61)$ were encouraged to join professional organizations, 78.5 percent $(n=51)$ were encouraged to volunteer for committee work, and 72.3 percent $(n=47)$ were encouraged to publish or present original research. A total of $5(7.7 \%)$ mentioned being encouraged to take classes, attend workshops, and present, but 3.1 percent $(n=2)$ were not encouraged at all to participate.

The residents' programs mostly encouraged or facilitated them to become involved in collaborations with other academic units on campus. Nearly half $(49.2 \% ; n=32)$ were able to build relationships with academic departments, 15.4 percent $(n=10)$ participated in faculty research, and 6.2 percent $(n=4)$ became academic advisors to campus organizations. Nearly 1 in $10(9.2 \% ; n=6)$ mentioned receiving help building relationships with student services units on campus and providing library instruction. Just under half $(41.5 \% ; n=27)$ were not encouraged to do so at all. More than two-thirds $(68.9 \% ; n=31)$ reported that their programs helped prepare them for the ongoing changes in the library profession, while 31.1 percent $(n=14)$ disagreed. The investigators wanted to know whether the library systematically used the residents' feedback to improve the program for future participants. While 56.5 percent $(n=35)$ said their libraries collected feedback, 33.9 percent $(n=21)$ said that their libraries 


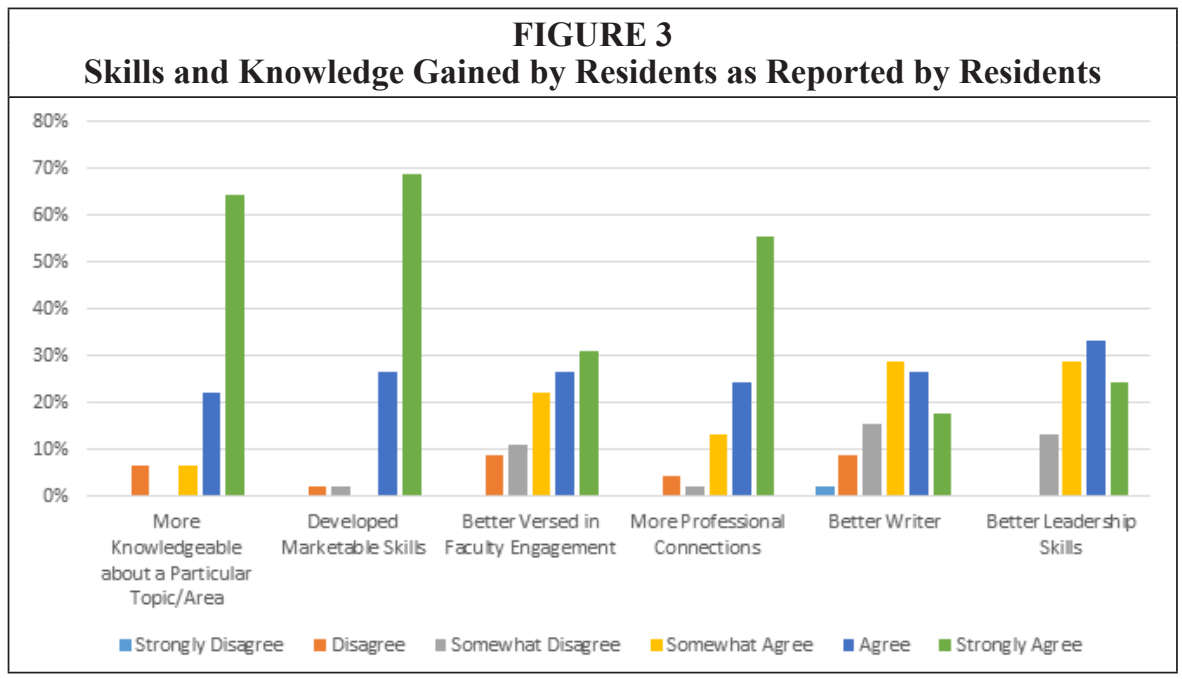

did not use the feedback they provided. Just over one-fourth $(25.8 \% ; n=16)$ were not asked for feedback at all.

Finally, the investigators wanted to know about the skills and knowledge gained during the residencies. All of the residents either agreed or strongly agreed that they had gained skills and knowledge. However, it is troubling that some of the residents indicated they were the least confident in the improvement of their writing skills, their abilities to engage with faculty, and their leadership skills (see figure 3).

All program coordinators highly encouraged residents to participate in the professional development activities asked about in the survey. A vast majority $(96.3 \%$; $n=$ 26) encouraged their residents to participate in professional organizations. Nearly that many $(85.2 \% ; n=23)$ highly encouraged their residents to publish and/or present original research. More than 4 out of $5(81.5 \% ; n=22)$ also encouraged their residents to participate in committee work. One program coordinator $(3.7 \%)$ mentioned that residents were required to do research and submit an article to a professional journal by the program's conclusion, and another stated their programs highly encouraged attendance at local workshops and lectures.

The programs mostly encouraged or facilitated residents to become involved in collaborations with other academic units on campus. Nearly three-quarters $(70.4 \%$; $=19$ ) highly encouraged or facilitated residents building relationships with academic departments. More than one-fourth $(29.6 \%$; $n=8)$ encouraged or facilitated residents' participation in faculty research, and 14.8 percent $(n=4)$ encouraged or facilitated their residents to become academic advisors to campus organizations. Nearly a quarter $(22.2 \% ; n=6)$ did not encourage or facilitate residents to become involved in collaborations with other academic units on campus.

More than 1 in $10(12 \% ; n=3)$ coordinators in the sample reported that their library does not systematically use residents' feedback to improve the program for future participants. However, 68 percent $(n=17)$ said that their residents did have the opportunity to work with their program coordinators, and 52 percent $(n=13)$ mentioned that the feedback collected in exit interviews was used to improve the programs.

Finally, coordinators were asked about the development of the skills and knowledge of the residents during their tenure. All $(100 \% ; n=27)$ strongly agreed or agreed that, by the end of the residencies, their residents were more knowledgeable about a particular topic or area. Nearly all $(92.6 \% ; n=25)$ of the coordinators also overwhelmingly strongly 


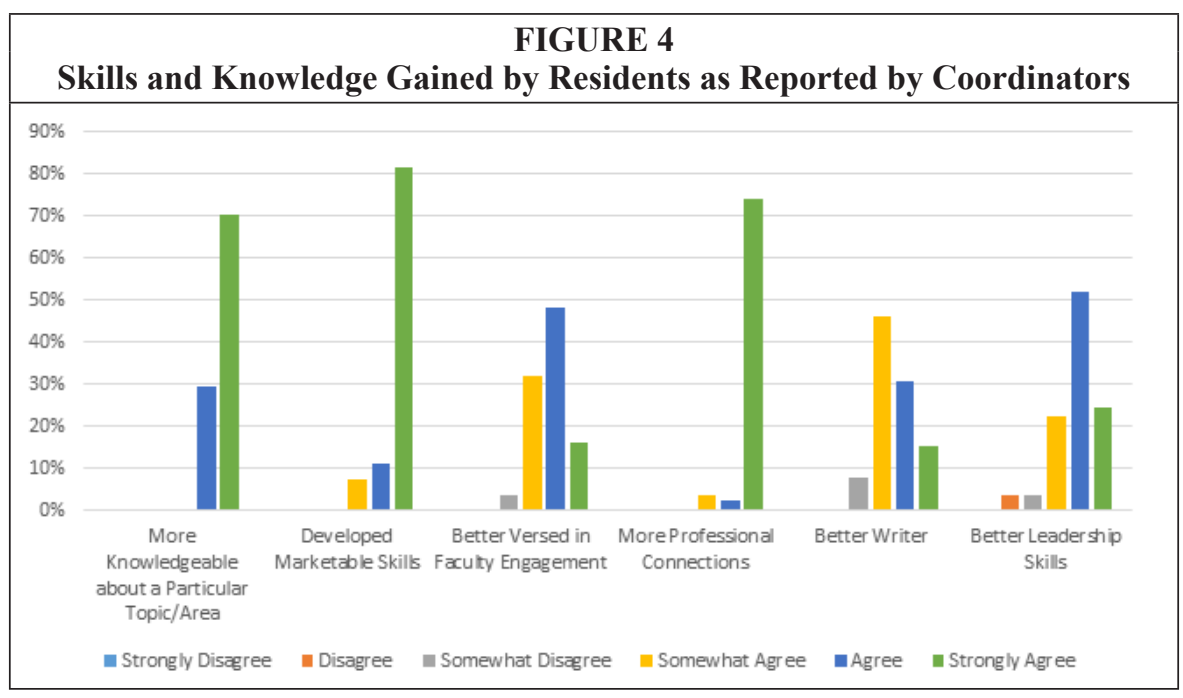

agreed or agreed that their residents had developed marketable skills. The other four skills the investigators inquired about had a more mixed response (see figure 4).

Coordinators reported that all of the programs had multiple missions and goals. The two most common missions and goals of the residencies were reported by 80 percent $(n=24)$ and 73.3 percent $(n=22)$, respectively, and this included mentoring new librarians and increasing diversity in academic libraries. Four out of 10 (40\%; n $=12$ ) had leadership development as a part of their mission or goal. Nearly a quarter $(23.3 \% ; n=7)$ used their residencies to recruit for subject specialization. In addition, one-third $(33.3 \% ; n=10)$ reported other missions and goals, such as: "[b]egin a research agenda"; "[b]ring innovative ideas, energy[,] and diversity of perspective to the library"; "[i]ncrease interest and exposure to academic librarianship"; encourage "[i]nternational exchange"; "[o]rganizational development"; "[r]ecruitment for special and needed skills and abilities"; and to "[m]ake up for lack of quality instruction training in LIS graduate programs."

In contrast to coordinators, 52.6 percent $(n=36)$ of the residents reported that the main mission and/or goal of their program was to increase diversity in academic libraries, 76.8 percent $(n=53)$ reported their program was focused on new librarian mentorship, 10.1 percent $(n=7)$ focused on subject specialization, 46.4 percent $(n=$ 32) focused on leadership development, 10.1 percent $(n=7)$ focused on recruitment for subject specialization, and 11.6 percent $(\mathrm{n}=8)$ selected "other." Those who chose "other" gave examples such as "research university library mentorship" and "to expose the resident to new technology and to utilize their skills in developing library projects."

As part of the coordinators' strategies to fulfill the missions and goals of their programs, they advertised and recruited for their programs using all types of methods. Nearly all $(96 \% ; n=24)$ advertised with listservs, while 80 percent $(n=20)$ used their own websites. Almost 7 out of $10(68 \% ; n=17)$ advertised in professional journals, and 52 percent $(n=13)$ advertised at conferences. A total of $4(16 \%)$ offered other methods, such as direct mailings to libraries and individuals and conducting in-person visits to library schools, and one coordinator relied heavily on word of mouth. Of those who recruited heavily at conferences, ALA was the most popular choice, with 92.3 percent $(\mathrm{n}=12)$ reporting it as their conference of choice. ACRL was also a popular choice, with 53.7 percent $(n=7)$ of coordinators advertising there. Two $(15.4 \%)$ mentioned ARL meetings and state library association conferences. 
Nearly half $(48.5 \%$; $n=32)$ of all residents learned of their residency programs through listservs, 42.4 percent $(n=28)$ through word of mouth, 28.8 percent $(n=19)$ on the residency websites, 7.6 percent $(n=5)$ through professional journals or didn't remember, and 6.1 percent $(\mathrm{n}=4)$ at conferences. A bit more than 1 out of $5(21.2 \%$; $\mathrm{n}=14$ ) said "other," such as the ALA JobLIST, social media, or a job placement center at a school.

\section{Activities of Residencies}

More than half $(57.1 \% ; \mathrm{n}=16)$ of the programs had more than one resident in a cohort. Roughly 4 out of $5(81.3 \% ; n=13)$ of the programs had two to three residents in their cohort. Two programs $(12.5 \%)$ had four to five residents, while 6.3 percent $(n=1)$ had six or more residents in their cohort. A vast majority $(93.8 \% ; n=15)$ of the coordinators thought that having a cohort increased the camaraderie amongst the residents. Just half $(50 \% ; n=8)$ of the coordinators saw another benefit to hosting a cohort-namely, that there were more dedicated people to devote to a given project. Coordinators gave other reasons for how a cohort benefited their residency program, including that it offered their library "[a]n opportunity to explore new projects without long-term commitments," "[m]ore diversity," a "[n]umber of new ideas," "[n]ew skills and fresh attitudes that were brought into the library," and "[r] esidents who were more integrated into the operations of the library, not seen as [an] isolated/special category of librarian." One coordinator also brought up an interesting point about cohorts making it slightly easier on all librarians. The coordinator pointed out that they have "staggered terms for [their] residents[,] which helps with training and mentoring as well as camaraderie." This also offers the incoming resident mentoring and training from a different perspective than could be offered by a supervisor, coordinator, or other librarians.

When asked if a larger cohort would give the library a greater benefit when considering the investment in a residency program, 54.5 percent $(n=12)$ of the coordinators did not think there would be a greater benefit, while 45.5 percent $(n=10)$ thought there would be a greater benefit. Most did not respond to whether there were any disadvantages or tradeoffs of having a residency cohort. Nearly 1 out of $5(18.75 \%$; $n$ =3) mentioned seeing no disadvantages or tradeoffs. One coordinator $(6.25 \%)$ mentioned that a tradeoff at their library was the amount of time needed for training and mentoring the residents. Another said, "I saw none when the program was in place. In addition to increasing our staff diversity, the regular rotation of new librarians with new perspective[s] and new ideas energized the entire staff."

When asked why the program decided to have only one resident at a time, two coordinators mentioned "budget," six coordinators mentioned "funding," one coordinator said, "don't know," one coordinator mentioned "past practice," and one coordinator mentioned "lack [of] funding for second residency position." In addition, a coordinator replied with the following statement: "[W]e have only 10 FT librarians, and are one large library unit (no departmental libraries); insufficient faculty and admin to mentor and supervisor two residents." Another coordinator stated that, in part, "[w]e're a medium-sized ARL. The library faculty are very supportive of the residency program. We do not have enough volunteers to supervise multiple residents or multiple departments that would offer simultaneous rotations..."

The investigators posed the following question: "Do you think that a larger cohort would give the library a greater benefit when considering the investment in your residency program? Why?" Coordinators responded that residents need the ability to talk to other residents who can mentor each other and not be seen as a special/isolated category of librarian. They also mentioned that a benefit of the larger cohorts was that they would compensate for the disadvantages of a limited permanent staff by provid- 
ing more staff (albeit temporary) who are available to help with new assignments and projects. However, in particular, one coordinator expressed a concern about library staff buy-in: "One has to work within resources available[.] [T] he number of interns isn't the key[;] the enthusiasm of current staff is the determining factor." Another coordinator stated, "We're not big enough to accommodate multiple residents; new librarians tend not to have backgrounds in tech, cataloging, or science[,] so frequently the same departments step up to mentor a resident."

Not all coordinators expressed positive impressions of having more than one resident at a time. For example, one noted, "Our cohort is generally 3 per year, and with a 2 -year program that means 2 cohorts of 3 (6 total residents at any given time). We have tried larger and it became unmanageable." Another program coordinator stated that he or she would like "[a]nother residency focused on new technologies [that] would benefit the library; two diversity residencies are not necessary."

Nearly two-thirds $(64.6 \%$; $=42)$ of the current and former resident respondents were part of a cohort. Almost 3 out of $10(29.2 \% ; n=19)$ were in a residency with two to three members in a cohort. One out of $5(20 \% ; n=13)$ were in a cohort of four to five. A total of $10(15.4 \%)$ were in a cohort of six or more. More than a third $(35.4 \% ; n=23)$ were the only residents in their programs, and 56.3 percent $(n=9)$ of all respondents felt they either had or would have benefited from having other residents in the program at the same time. Nearly half $(43.8 \% ; n=7)$ did not feel they would have benefited from having other residents in the program at the same time. Of particular note, 77.8 percent $(n=12)$ of residents of color felt they would have benefited from having other residents in the program at the same time.

Nearly two-thirds $(65.4 \% ; n=17)$ of the program coordinators offered formal mentoring to their residents, while 34.6 percent $(n=9)$ offered informal mentoring. Of those who had a formal mentoring program in place, the vast majority offered assigned mentors and regular meetings with supervisors. Close to 9 out of 10 (87.5\%; $\mathrm{n}=7$ ) did not believe that a formal mentoring program would be beneficial to their residents, while 12.5 percent $(n=1)$ did believe the program would benefit from having a formally structured mentoring program. More than 4 out of $5(81.3 \% ; n=13)$ assigned mentors and regular meetings with supervisors. More than half $(56.3 \%$; $n=$ 9) offered their residents help or support for first-time conference attendees. Finally, 43.8 percent $(n=7)$ offered career mentoring and specialized trainings or workshops.

Some residents sought out ways to connect with others in similar positions outside their home library to obtain a sense of group membership and support. Residents who did not have other residents in their programs offered the following reasons to include cohorts in a residency program: for example, a resident stated, "[W]e have a regional residency group that meets annually that has been a really wonderful professional group to work with." Another resident gave the following reason: "I was the first resident at my university. I don't think there was and is a ton of cultural buy-in. I still don't think a lot of library staff know or understand what a residency is or does. I was constantly explaining what I did and why I was there. (That's exhausting[.]) I think the experience is extremely unique, and while I reached out to other residents around the country, since they were at different stages of their residency, it wasn't quite the same. I think it would be a lot less stressful to have someone to bounce ideas or stresses off of." Furthermore, the resident expressed a concern about microaggression: "It would also be nice to have an environment in which to safely share the microaggressions that I think are experienced on a regular basis by someone with a 'diversity' tag on their title."

Another resident stated, "It was very difficult to be the only resident. Although I had great support and relationships with other early-career librarians at my institu- 
tion, I still felt isolated." Another resident also stated, "It would have been nice to have another resident to collaborate and work with." In addition to mutual support and encouragement, one resident said, "The benefit of having multiple residents is the ability to share experiences and ideas on how to improve the residency program."

Nearly two-thirds $(65.7 \% ; \mathrm{n}=44)$ of the residents participated in formal mentoring, while 26.9 percent $(\mathrm{n}=18)$ participated in informal mentoring. More than 9 out of 10 (90.9\%; $n=40)$ received assigned mentors, 63.6 percent $(n=28)$ held regular meetings with supervisors, 36.4 percent $(n=16)$ received career mentoring, 29.5 percent $(n=13)$ received specialized trainings and workshops, and 27.3 percent $(n=12)$ were helped or supported as first-time conference attendees. A total of $3(6.8 \%)$ gave "other" as an answer but did not give any examples. Only 5 (7.5\%) of the respondents were offered no mentoring. Of those who had an informal or no mentoring program, 66.7 percent $(n=12)$ thought the program would benefit from a formally structured mentoring program, while 33.3 percent $(n=6)$ disagreed.

As mentoring is a major aspect of a successful residency program, coordinators were asked about the mentoring structure and the defined outcomes for residents. There were five coordinators whose responses were "none or not defined." Several coordinator responses involved similar approaches. Selected responses included: "[g]uidance in library processes, culture, etc.; help in determining career directions; help in navigating campus and developing relationships with other campus units;" and "connecting with peers." Another respondent believed that "[a]ll new librarians have the opportunity to participate in the formal mentoring program coordinated by the librarians' association," and another respondent replied that "[r]esidents have many informal mentoring opportunities as well, especially with supervisors, administrators, and former residents on staff."

In regard to the question about "why a formally structured [mentoring] program [had] not been implemented," a coordinator described a situation that did not allow the coordinator much time for comprehensive, strategic planning of the program. The program was restricted by a compressed timeline that included constructing and implementing the program, getting funding and approval from the Provost's office, advertising, and interviewing and getting the residents on campus. The coordinator then had to find candidates willing to interview and start the residency within two weeks of the job posting.

When the investigators asked the residents to define the outcomes for their mentoring experiences, whether they were formally or informally structured, residents listed receiving help for "[c]areer planning," "[e]arly-career development," "C.V. development [and] socialization into the profession, etc." Residents also mentioned benefiting from "[l]eadership development and project management skills, [...] networking," "[c]ompletion of projects under the mentorship of a department head librarian," as well as providing "[m]onthly [o]utcomes-based evaluations and [r]eports." However, several residents were unclear whether there were defined outcomes.

For early-career librarians or recent graduates in a residency program, there were benefits from structured mentoring. Residents who did not receive this type of mentoring responded as to why they would have benefited from a structured mentoring program. One resident mentioned that the "program assumed that my supervisor would act as a mentor but that did not happen. It did happen for other residents and really enhanced their experiences." Another mentioned that he or she would have liked "an assigned mentor so I could have focused on the specific field of librarianship I wanted to enter into." Others mentioned that "[1]earning to navigate a large organization is difficulty [sic] to do, and the mentoring I received was invaluable"; that the mentoring "would provide a greater sense of support and opportunities to build more relationships"; and that "[t]he mentor could propose ideas/issues the resident might not foresee." 
A majority of program coordinators did not require a capstone project of their residents. Nearly 7 out of $10(69.2 \% ; n=18)$ did not require a completion of a capstone project, while 30.8 percent $(n=8)$ did have such a requirement for their residents. Almost two-thirds $(62.5 \% ; n=5)$ programs reported that their residents negotiated their capstone project with the library. A quarter $(25 \%$; $n=2)$ stated that residents chose projects according to their interests, while 12.5 percent $(n=1)$ reported that the library chose the capstone project for the resident.

While residents answered a similar question about capstone projects, the coordinators responded with several examples that demonstrated institutional buy-in to ensure that residents succeeded in the programs. The examples included: "[d]esign and administration of a user survey"; preparation of "a records management proposal for the institution"; "[e]ngaging international students in the Library's services[,] developing basic syllabi for a series of walk-in IL sessions[,] creating a model for embedding librarian[s] into Bb shells for online or regular classes"; "a research project and present[ing] or publish[ing]"; and "chat reference evaluation."

Since participating in a capstone project - whether it involves publishing, presentations, or committee work - enhances an academic librarian's professional development, the survey posed a question to the residents regarding their involvement in such a project. Several residents were active in a variety of projects, such as redesigning the library's website, developing the "1st ever Best Practices Guide for CONTENTdm users," web archiving, and developing an oral history project. One resident stated, "My project was to work on how we gather data and statistics about the library system"; another resident stated, "My capstone was a Power[P]oint with embedded video interviews of all of the people that I worked with, basically giving a recap of all of that I had accomplished during the residency"; and another resident stated, "Library intranet."

The majority of the resident respondents, 62.2 percent $(n=28)$, were not expected to complete a capstone project. More than a third $(37.8 \% ; n=17)$ were expected to, had completed, or planned to complete a capstone project. Of those who were expected to complete a capstone project, 41.2 percent $(n=7)$ reported that their library picked a project for them. Fully one-third $(35.3 \% ; n=6)$ picked a project according to their interests, while 23.5 percent $(n=4)$ negotiated a capstone project with the library.

Of the professional activities the residents participated in, 93.7 percent $(n=59)$ joined professional organizations, 79.4 percent $(n=50)$ volunteered for committee work, 68.3 percent $(n=43)$ published or presented original research, and 1.6 percent $(n=1)$ did nothing. Nearly 1 in $10(9.5 \% ; n=6)$ mentioned mentoring in other types of professional activities, such as conducting funded research, presenting a poster session, and attending webinars and trainings.

\section{Acculturation to Other Academic Units on Campus}

The investigators also asked the coordinators to respond to the question "How do you help them [the residents] acculturate to other academic units on campus?" One coordinator said that, for example, "Our residents work with interdisciplinary academic programs such as honors, specialized retention programs, and our English Language Institute. They also liaise with Student Affairs offices such as the Office of Multicultural Affairs. [T]heir supervisor introduces them and we usually pair them with an experienced librarian to help them 'learn the ropes.'" Another coordinator noted that "[t]he Diversity officer mentors the resident to be successful in academic librarianship vis a vis [sic] scholarship, professional development." And a third coordinator offered, "We provided background information and introductions to key staff in the campus groups with which they collaborated." 
Some current and former residents talked about the channels through which their residency program helped them acclimate to campus life. To help residents acculturate to other academic units on campus, one program "[d]esignated campus groups [to the Diversity Resident] (i.e. the Office of Multicultural Affairs)" and allowed the resident to "discuss with [his or her] mentor any questions/issues [he or she had] with the academic unit."

Residents provided numerous examples regarding the benefits of acculturation. One resident stated, "Assisted in networking. Librarians modeled collaborative relationships with classroom faculty. The expectation to be active and engaged with classroom faculty was communicated clearly throughout [the] organization." Another resident said, "By providing exposure to other units. This is a very visible residency." And another resident stated, "I was given three subject areas to manage, and so the program was a 'sink or swim' introduction to building liaison relationships with departments." One resident stated, "Encouraged us to introduce ourselves, but most attempts to get to know other parts of the university and even the library system were up to us."

\section{Program Improvement Information/Assessments}

The investigators posed two separate questions to ascertain as much detail as possible regarding how to determine the success of a residency program. In responding to the question "What kind of program improvement information do you usually collect?" one coordinator stated: "Evaluation of orientation program," including "information on the effectiveness of [their] mentor, the assignment rotation system, there [sic] yearlong assignment, their understanding of the clarity of expectations set out for them, and their impressions of the overall welcoming environment for them in the library." Another reported that "[s]everal years into the program we conducted a retreat with current and former residents and supervisors to get recommendations on the entire program and we implemented various suggestions, including adding a 'graduation ceremony' at the end."

Coordinators have used the following methods and metrics in assessing their programs: "[s] urveys of past participants," the rate of "[e]mployment after the residency," the "[s]trength of [the] second-year project," and "[i]ntegration into the program." Coordinators also received feedback through "[a]nnual and quarterly evaluations from residents and supervisors, informal discussions with residents, supervisors, and mentors; formal discussions with [the] library management team; tracking career development of past residents; [the] number and quality of requests from supervisors to host a resident; [the] amount of awareness and quality of perceptions of the program in the research library community." However, two coordinators did not provide information on assessment with the statements "Don't know" and "None really."

\section{Changes Coordinators Would Like to See in Their Programs}

Regarding changes they would like to see in their residency programs, a coordinator responded about a program that was no longer active and that he or she wanted to see reinstated: "[O]ur program is dormant because of changes in the way the state and our institution deal with underrepresented groups... The residents added a great deal to the Libraries. The other thing I would change if we reinstated the program would be to increase the involvement of other staff with the residents. We have very little diversity on the staff, and encountered some attitudinal issues (i.e. thinking the residents were student assistants, treating them differently than other colleagues, etc.). Having residents rotate among departments would be a good change to the program." Another coordinator stated, "[E]xtend to three year, underway; more flexibility in departmental assignment to match interests of candidates; and, more flexibility in department assign- 
ment to match needs of Library." Common themes involved adding a second resident and extending the length of the program.

\section{Recommended Residency Program Changes}

The "otherness" that is inherent in such a position as a diversity library resident emphasizes the need for formal mentoring with defined outcomes, as well as peer support through a cohort. The singling out of library residents as "different" from the rest of the library staff had a negative impact on resident experiences. One resident stated that one thing he or she would like to have seen changed about the program was "[m]y position title (Minority Librarian)." Sensitivity to how such titles are perceived by librarians, staff, and the greater community must be considered in the naming of library residency positions. In essence, merely bringing a diversity library resident into a library could make residents feel like outsiders. Said one resident, "I was the single minority with a library faculty and staff of over 30." In that same vein, another resident stated, "[t]hings were slightly tenuous for me. I had to feel things out." Said one resident, "I would have liked more opportunities for my supervisors to let me know how I'm doing. Sometimes I feel very isolated as an intern." Another resident stated, "As a visible minority, I've also experienced microaggressions that made me feel like I didn't belong in the profession. This is a problem that needs to be acknowledged and taken seriously." Said one respondent, "I definitely felt like I had to work 4 times as hard and do it twice as cheery because of my race and my residency status[,] along with confusion about the position from some staff." In addition, this resident expressed, "Most importantly, however, I really, really, [sic] wish that those in the library had a greater understanding of diversity and why residency programs are imperative to the growth of libraries as relevant cultural institutions in the future. But, I imagine many minorities in this field probably feel the same way regardless of their title."

Especially in libraries where there is institutional buy-in, extra steps must be taken to prepare residents for different types of environments they may encounter after leaving their residency, as evidenced by a response from a resident who wished a mentor might "[h]ave [had] discussions to prepare [them] for working in other institutions that do not share the value of diversity. [The resident] felt great while in the residency program. But once [they] became more senior, [they] ran into career advancement problem [sic]. Asians are not considered to be leadership materials [sic]." One resident stated the desire for an "opportunity to rotate in selected areas of interest, more integration of diversity projects (without singling out the resident as the go-to person for all things related to diversity), [and] more discussions about capstone projects and the eventual job search." One resident recommended avoiding "calling the program an 'internship;' this title makes it difficult to not only create relationships with faculty (they thought we didn't have degrees yet), but also created some divides with our professional peers who treated us more like students than colleagues." Also, there were several responses with the common themes regarding the length of the residency program, such as a "longer amount of time," the need for mentoring, and the benefit of recruiting cohorts in programs.

Other comments included:

- "It certainly would have been really nice to have another resident going through the same thing, (or even a year ahead)."

- "I would like for the Library to clearly distinguish where Fellows fall in the organizational hierarchy[,] because I have felt that I was being taken advantage of because of my status by a librarian who was not my supervisor."

- "Rotations between departments." 
- $\quad$ "I would have liked a capstone project[;] I would have liked feedback from all the departments I worked in so I could know where to improve[;] [and] I would have liked more communication and support upon completing the program."

The above comments highlight the importance of residency programs with respect to institutional buy-in, as well as addressing the concerns and needs of the residents.

\section{Limitations}

While our findings resulted in discovering several aspects of a successful diversity residency program and the benefits for both the resident and the institution, the investigators encountered a few challenges. Because of this, it may be difficult to come to conclusions. This research was exploratory in nature; and, while further research should be conducted, the investigators believe that our findings can be used to strategically implement new, or improve active, academic library residencies.

As noted by other researchers of residency programs (who were mentioned in the literature review), to this day there is no central database of all residency programs that have existed over time. If the population cannot be enumerated, there is no way to determine the reliability or the representativeness of the responses as they might pertain to an entire population of coordinators and residents. A centralized database holding the information of all programs, both active and inactive, as well as a way to reach all current and former residents, would likely have increased our sample size.

The survey results may be skewed for a few reasons. For example, only those who were motivated or interested enough in the subject of the survey responded. The answers received reflect only the views of those motivated or interested enough to respond, which can lead to biased results. There may have also been self-exclusion from the survey because there may have been a misunderstanding about exactly to whom the survey applied. As noted earlier in this paper, there is no standard terminology for this type of program, with the terms "residency," "internship," and "fellowship" being used most frequently and interchangeably. There may be some who do not have the term "resident" in their job title or their job description and who did not participate because they may not have realized that the survey applied to them.

In addition, the investigators did not separate the responses of former and current residents. Two-thirds of our respondents were former residents, which may mean the responses collected skew toward overrepresentation of former residents and older programs. With the coordinators, however, 51.7 percent of the sample included programs that had been active for zero to five years (2006 to 2012). This may skew the results toward newer programs.

Perhaps because of the length of the survey, coordinators submitted 22 incomplete surveys, while current and former residents submitted 112 incomplete surveys. Thus, the ability to weigh and compare responses was limited.

Finally, the data was all self-reported. This means the responses were subject to recall bias. There may be faded memories or reluctance to report based on inability to confirm certain details. This was highlighted by one coordinator who regretted that "[t]his information is not readily available since the program was discontinued more than 20 years ago!" There may have also been some misunderstanding of the survey questions. Due to the anonymous nature of the survey, the investigators could not clarify any questions or misunderstandings that may have occurred.

\section{Conclusions}

A library residency program is one of many types of recruitment measures that libraries can use as part of a larger diversity initiative. Kulik and Roberson noted that organizations have not received much practical guidance on "how to choose from the many 
possibilities available when designing their own diversity management strategy," which highlights the need for future research. ${ }^{61}$ The study identified several aspects of residency programs that successfully prepared new graduates and early-career librarians for the profession, such as offering formal/structured mentoring, requiring capstone projects, assigning rotations in different library departments, facilitating involvement in diversity activities, increasing leadership training, and developing marketable skills.

The findings from this survey show that individuals who participate in residency programs tend to stay within the library profession. The majority of qualitative responses from current and former residents indicate that, while they gained valuable applied librarian skills, their residency programs did not prepare them for challenges they would face in the library profession as a person of color. This may indicate a need for long-term mentoring and/or camaraderie beyond the library residency.

While residencies can inject a measure of diversity into an ethnically homogenous institution by the numbers, the "diversity" label does not help with attitudinal diversification within the staff as a whole. To effectively implement diversity residency programs, institutions must emphasize their organizational buy-in, structure formal mentoring programs, use cohorts to transfer knowledge, and facilitate socialization for residents. These components benefit the residents in priming them for a career in academic libraries and all of the impending challenges librarians of color face. They also benefit the host library through the provision of service that reflects its users. This fosters diverse perspectives and engenders creativity and innovation.

There exist environments where many librarians do not feel the need to diversify the academic library profession to better serve its users, and therefore the number of minorities in the LIS field must increase to create a marked attitudinal change. Educational and professional recruitment measures serve as a first step, while library residency programs serve a critical role in retention to ensure those numbers are maintained and will eventually increase to match the shifting demographics of college students and faculty in the United States.

For a diversity resident, participating in a cohort was considered an important part of the residency. Residents in a cohort are able to mentor each other. In addition, a cohort can provide peer support for residents who might otherwise have been singled out as "different" from the rest of the library staff. This mentorship opportunity also addresses not only immediate challenges for residents; it also provides a network for future career aspirations.

Since residencies are available to individuals after they have already decided to pursue their library degrees, they serve not so much as programs to recruit LIS students of diverse backgrounds as much as to develop and maintain the leadership capacity of the librarians so that they in turn may recruit and mentor early-career librarians of color. Residencies play a vital part in a multipronged professional diversification process that involves not only single institutions but also the entire LIS profession. Recruiting graduates of diverse backgrounds through library residency programs ensures that there are increased efforts in our profession to recruit and retain for diversity to reflect the demographic changes in the American population. As shown in the survey results, residents of color across the board are more likely to become engaged in efforts to promote diversity in academic librarianship. As these efforts gain momentum, the academic library community will be better prepared to face future challenges in the increasingly pluralistic and competitive world of the twenty-first century. Regardless of the bans on affirmative action currently in eight of the United States, the authors highly encourage academic libraries to institute residencies geared toward recruiting and promoting diversity in academic librarianship. 


\section{APPENDIX A. 2012 Residency Survey Instrument- Coordinators}

1. When was your residency program established? [YEARS, starting 1980-2013]

2. For how many years has your residency program been active? [NUMBERS, starting $0-35]$

3. Is your residency program still actively recruiting?

a. Yes

b. No

4. When did you last actively recruit for your residency program? [YEARS, starting 1980-2013]

5. Why is your program no longer recruiting?
a. Lack of financial support
b. Lack of administrative support
c. Lack of available librarians to train/mentor residents
d. Ban on affirmative action measures
e. Other (please specify):

6. Do librarians at your institution have faculty status?
a. Yes
b. No

7. How long is/was your residency program? $<1 / 1 / 2 / 3 / 4+$ years

8. Is your residency a full- or part-time position?

a. Full-time

b. Part-time (please specify hours per week)

9. What are the main mission and goals of your residency program?
a. Increase diversity in academic libraries
b. New librarian mentorship
c. Recruitment for subject specialization
d. Leadership development
e. Other (specify):

10. How do you define diversity for your residency program?

a. Underrepresented people of different races or cultures

b. Socioeconomic status

c. Age

d. Gender

e. Geography

f. Sexual orientation

g. Physical ability

h. Language

i. Religion

j. Life experience

k. Specialized skills that are not currently held by anyone at your institution

1. Other (specify):

11. How does your residency program weigh diversity in the selection of candidates?

12. Do you provide professional development funds to residents?
a. No
b. Yes, conference attendance
c. Yes, continuing education (training, webinars, workshops)
d. Yes, continuing education (advanced degrees)
e. Professional memberships
f. Research
g. Other (specify): 
13. What is your approximate annual budget for professional development funds to residents?

14. What is the hourly pay range for residents?

a. Unpaid

b. Less than $\$ 10.00$

c. $\$ 10.00-\$ 12.00$

d. \$12.00-\$14.50

e. $\$ 14.50-\$ 17.00$

f. $\$ 17.00-\$ 19.00$

g. $\$ 19.00-\$ 21.50$

h. $\$ 21.50-\$ 24.00$

i. $\$ 24.00-\$ 26.50$

j. $\quad \$ 26.50-\$ 29.00$

k. $\$ 29.00-\$ 31.00$

l. $\$ 31.00-\$ 33.50$

m. More than $\$ 33.50$

15. What is the starting hourly pay range for regular librarians at your residency institution?
a. Less than $\$ 10.00$
b. $\$ 10.00-\$ 12.00$
c. $\$ 12.00-\$ 14.50$
d. $\$ 14.50-\$ 17.00$
e. $\$ 17.00-\$ 19.00$
f. $\$ 19.00-\$ 21.50$
g. $\$ 21.50-\$ 24.00$
h. $\$ 24.00-\$ 26.50$
i. $\$ 26.50-\$ 29.00$
j. $\$ 29.00-\$ 31.00$
k. $\$ 31.00-\$ 33.50$
1. More than $\$ 33.50$

16. What are the sources of funding for your residency program?
a. Grant funding
b. Library funding
c. Foundations
d. Other (specify):

17. Library funding for your residency program includes:
a. State allocation
b. Tuition
c. Other (specify):

18. How and where do you advertise the residency program?

a. Professional journals

b. Listservs

c. Websites

d. Conferences

e. Other (specify):

19. In which conferences have you recruited for your residency program?

a. Association of College and Research Libraries

b. American Library Association (Annual and/or Midwinter)

c. Special Library Association

d. Other (specify): 
20. What kind of mentoring do residents receive through your program?
a. Formal
b. Informal
c. None

21. How is your mentoring program structured?

a. Assigned mentors

b. Career mentoring

c. Help or support for first-time conference attendees

d. Specialized trainings and workshops

e. Regular meeting with supervisors

f. Other (specify):

22. What are/were defined outcomes for the mentoring of residents?

23. Do you think your program would benefit from having a formally structured mentoring program?
a. Yes
b. No

24. Why has a formally structured program not been implemented?

25. Do you encourage residents to participate in any of these professional development activities?
a. Professional organizations
b. Committee work
c. Publishing and/or presenting original research
d. None
e. Other (specify):

26. How is the resident's assignment determined?

a. Residents choose their assigned department(s) according to their interests

b. Residents choose their assigned department(s) according to library needs

c. Assigned department(s) is predetermined by the library

d. Residents negotiate assignment(s) with the library

27. How is the resident's assignment structured?
a. Rotations in various departments
b. Standing assignment with focus
c. Other (specify):

28. What departments are residents assigned to during their term?
a. Technical services
b. Outreach
c. Reference and instruction
d. Access services
e. Data curation (data management and preservation initiatives)
f. Digital preservation
g. Digital image collections
h. Other (specify):

29. Does the program encourage or facilitate residents to become involved in collaborations with other academic units on campus?
a. No
b. Yes, building relationships with academic departments
c. Yes, participating in faculty research
d. Yes, becoming academic advisors to campus organizations

30. How do you help them acculturate to other academic units on campus?

31. Do you have more than one simultaneous resident in your program?
a. Yes
b. No 
32. How many simultaneous residents do you have?
a. 1
b. $2-3$
c. $4-5$
d. 6 or more

33. How does having a residency cohort benefit your library?

a. Camaraderie among residents

b. More dedicated people to devote to a given project

c. Other (specify):

34. What are the disadvantages or tradeoffs of having a residency cohort at your library?

a. More resources (time and money) required to maintain the program

b. Other (specify):

35. Why have you decided to have only one resident in your program at a time?

36. Do you think that a larger cohort would give the library a greater benefit when considering the investment in your residency program?
a. Yes
b. No

37. Why?

38. Does your program require residents to complete a capstone project?
a. Yes

b. No

39. How do you determine what kinds of projects they work on?

a. Resident chooses a capstone project according to his or her interests

b. Resident chooses a capstone project according to a list provided by the library

c. Resident negotiates capstone project with the library

d. Library chooses a capstone project

40. Please list some example capstone projects:

41. Does the library systematically use residents' feedback to improve the program for future participants?

a. No

b. Yes, residents have the opportunity to work with the program coordinator

c. Yes, through the feedback collected in exit interviews

42. What kind of information do you usually collect for program improvement?

43. By the end of your program, would you say that residents: [SCALE: Strongly agree, agree, somewhat agree, somewhat disagree, disagree, strongly disagree]

a. Are more knowledgeable about a particular topic/area?

b. Have developed marketable skills?

c. Are well-versed in faculty engagement?

d. Had more professional connections?

e. Are improved writers?

f. Have acquired leadership skills?

44. What methods have you used to assess the success of your program?

45. What are 1-3 things you would like to change about your residency program? 


\section{APPENDIX B. 2012 Residency Survey Instrument- Residents}

1. Are you currently in a residency program?

a. Yes

b. No, I'm a former resident

2. At what institution is/was your residency program based?

a. Auburn University

b. Cornell University

c. Kansas State University

d. Library of Congress

e. Marquette University

f. National Library of Medicine

g. North Carolina State University

h. The Ohio State University

i. Santa Barbara City College

j. Syracuse University

k. Towson University

1. University of Arkansas

m. University of California at Santa Barbara

n. University of Delaware

o. University of Illinois at Chicago

p. University of Louisville

q. University of North Carolina at Greensboro

r. University of Notre Dame

s. University of Pennsylvania

t. University of Pittsburgh

u. University of Southern California

v. University of Tennessee

w. University of West Georgia

x. Vanderbilt University

y. Western Washington University

z. Yale University

aa. Other (please specify):

3. When did/will you complete, or expect to complete, your residency program? [YEARS, starting 1980-2016]

4. How long is/was your residency program? $<1 / 1 / 2 / 3 / 4+$ years

5 . Is/was your residency a full- or part-time position?

a. Full-time

b. Part-time (Please specify hours/week)

6. What is your current position title?

a. Collection Manager

b. Reference Librarian

c. Instruction Librarian

d. Cataloging Librarian

e. Metadata Librarian

f. Department Head

g. Associate University Librarian

h. University Librarian/Library Dean

i. Currently in residency program

j. Position not related to libraries

k. Other (specify): 
7. What library department are you currently affiliated with?
a. Technical Services
b. Outreach
c. Reference and Instruction
d. Access Services
e. Data Curation (Data Management and Preservation Initiatives)
f. Digital Preservation
g. Digital Image Collections
h. Information Technology/Systems
i. Human Resources
j. Other (specify):

8. What are/were the main mission and goals of your residency program?
a. Increase diversity in academic libraries
b. New librarian mentorship
c. Recruitment for subject specialization
d. Leadership development
e. Other (specify):

9. As a resident, are/were you involved in any efforts to promote diversity in academic librarianship?
a. No
b. Yes, mentoring
c. Yes, career coaching
d. Yes, financial assistance
e. Yes, presentations
f. Yes, panel discussions
g. Other (specify):

10. Are/were you provided professional development funds during your residency?
a. No
b. Yes, conference attendance
c. Yes, continuing education (training, webinars, workshops)
d. Yes, continuing education (advanced degrees)
e. Professional memberships
f. Research
g. Other (specify):

11. Approximately how much have/did you receive annually for professional development?

12. What is/was the hourly pay range for residents?
a. Unpaid
b. Less than $\$ 10.00$
c. $\$ 10.00-\$ 12.00$
d. $\$ 12.00-\$ 14.50$
e. $\$ 14.50-\$ 17.00$
f. $\$ 17.00-\$ 19.00$
g. $\$ 19.00-\$ 21.50$
h. $\$ 21.50-\$ 24.00$
i. $\$ 24.00-\$ 26.50$
j. $\$ 26.50-\$ 29.00$
k. $\$ 29.00-\$ 31.00$
1. $\$ 31.00-\$ 33.50$
m. More than $\$ 33.50$ 
13. What is/was the starting hourly pay range for regular librarians at your residency institution?
a. Less than $\$ 10.00$
b. $\$ 10.00-\$ 12.00$
c. $\$ 12.00-\$ 14.50$
d. $\$ 14.50-\$ 17.00$
e. $\$ 17.00-\$ 19.00$
f. $\$ 19.00-\$ 21.50$
g. $\$ 21.50-\$ 24.00$
h. $\$ 24.00-\$ 26.50$
i. $\$ 26.50-\$ 29.00$
j. $\$ 29.00-\$ 31.00$
k. \$31.00-\$33.50
1. More than $\$ 33.50$

14. How and where did you find out about the residency program?
a. Professional journals
b. Listservs
c. Websites
d. Conferences
e. Word of mouth
f. Don't remember
g. Other (specify):

15. What kind of mentoring do/did you receive through your program?
a. Formal (the library assigned you a mentor during your residency)
b. Informal (you identified and developed relationship with mentor on your own)
c. None

16. How is/was the mentoring program structured?
a. Assigned mentors
b. Career mentoring
c. Help or support for first-time conference attendees
d. Specialized trainings and workshops
e. Regular meeting with supervisors
f. Other (specify):

17. What are/were defined outcomes for the mentoring of residents?

18. Do you think your program would benefit/has benefited from having a formally structured mentoring program?
a. Yes
b. No

19. Why do you think you would have benefited from a structured mentoring program?

20. Are/were you encouraged to participate in any of these professional development activities during your residency?
a. Professional organizations
b. Committee work
c. Publishing and/or presenting original research
d. None
e. Other (specify):

21. In which of the following professional activities have you actually participated?

a. Professional organizations

b. Committee work 


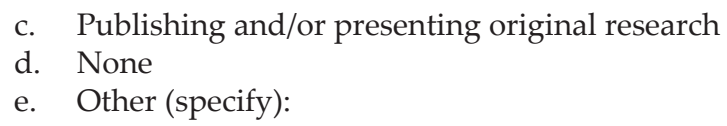

22. How is/was the resident's assignment structured?

a. Rotations in various departments

b. Standing assignment with focus

c. Other (specify):

23. What departments among those to which you were assigned had the most impact on your career?
a. Technical Services
b. Outreach
c. Reference and Instruction
d. Access Services
e. Data Curation (Data Management and Preservation Initiatives)
f. Digital Preservation
g. Digital Image Collections
h. Information Technology/Systems
i. Other (specify):

24. Does the program encourage or facilitate residents to become involved in collaborations with other academic units on campus?
a. No
b. Yes, building relationships with academic departments
c. Yes, participating in faculty research
d. Yes, becoming academic advisors to campus organizations
e. Other (specify):

25. How does/did the program help you acculturate to other academic units on campus?

26. Did your program help you prepare for the ongoing changes in the library profession?
a. Yes

b. No

27. How did your program help you prepare for ongoing changes in the library profession?

28. How many simultaneous residents are/were there in your program?
a. 1 (only you)
b. 2-3
c. $4-5$
d. 6 or more

29. Do you think you have benefited from having other residents in the program with you?

a. Yes

b. No

30. Please explain how having other residents in the program would have benefited you:

31. Are you expected to/Did you complete a capstone project?
a. Yes
b. No

32. How is/was this project assigned to you?

a. Resident picks a capstone project according to his or her interests

b. Resident picks a capstone project according to a list provided by the library

c. Library picks a capstone project

d. Resident negotiates capstone project with the library 
33. What is/was your capstone project?

34. Does/Did the library systematically use residents' feedback to improve the program for future participants?

a. No

b. Yes, residents have the opportunity to work with the program coordinator

c. Yes, through the feedback collected in exit interviews

35. By the end of your program, would say that you: [SCALE: Strongly disagree, disagree, somewhat disagree, somewhat agree, agree, strongly agree]
a. Were more knowledgeable about a particular topic/area?
b. Developed marketable skills?
c. Were better-versed in faculty engagement?
d. Had more professional connections?
e. Were a better writer?
f. Had acquired better leadership skills?

36. What is your gender?
a. Male
b. Female

37. What ethnicity do you most identify with?
a. White
b. Spanish, Hispanic, or Latino/a
c. African American
d. Native American, or Alaskan Native
e. Asian American
f. Native Hawaiian, or other Pacific Islander
g. Biracial or multiracial
h. Other

38. What is your age? [AGES, starting 18-99]

39. What are 1-3 things you would (have) like(d) to change about your residency program? 


\section{APPENDIX C. List of Library Residencies (both active and inactive) that researchers discovered}

Note: The programs that are in bold font were part of the original survey. Those programs marked with an asterisk $(*)$ are currently inactive as of this writing. (Please check with the ACRL Residency Interest Group and each institution for the most up-to-date information.)

\section{Canada}

- University of Alberta

- University of New Brunswick*

\section{Alabama}

- Auburn University

\section{Arizona}

- University of Arizona*

\section{Arkansas}

- University of Arkansas

\section{California}

- Academy of Motion Picture Arts and Sciences

- Autry National Center

- California State University at Northridge

- California State University at San Luis Obispo

- Los Angeles Public Library

- Loyola Marymount University

- Santa Barbara City College

- University of California at Santa Barbara

- University of Southern California

- University of California at San Diego*

\section{Colorado}

- University of Northern Colorado*

\section{Connecticut}

- Darien Library

- Yale University-Kress Fellowship in Art Librarianship

- Yale Law Library-Rare Book Fellowship

\section{Delaware}

- University of Delaware

- District of Columbia (DC)

- American University

- Army Research Library

- Georgetown University Law Library*

- Library of Congress

- Smithsonian Institution

\section{Florida}

- University of South Florida* 


\section{Georgia}

- Center for Disease Control Public Health Library and Information Center*

- Emory University

- University of West Georgia

\section{Illinois}

- College of DuPage*

- University of Chicago

- University of Illinois at Chicago

- University of Illinois at Urbana-Champaign*

\section{Indiana}

- Purdue University*

- University of Notre Dame

- Valparaiso University

\section{lowa}

- University of Iowa

\section{Kansas}

- Kansas State University

\section{Kentucky}

- University of Louisville

\section{Maryland}

- Johns Hopkins School of Medicine

- National Library of Medicine

- Towson University

\section{Massachusetts}

- Massachusetts Institute of Technology

- National Digital Stewardship Residency Program

- University of Massachusetts Medical School

- University of Massachusetts at Amherst*

- University of Massachusetts at Worcester*

\section{Michigan}

- Northern Michigan University*

- University of Michigan*

- Wayne State University*

\section{Minnesota}

- Minnesota State University at Mankato

- University of Minnesota*

\section{New Jersey}

- Rutgers University

\section{New Mexico}

- University of New Mexico* 


\section{New York}

- Cornell University

- Cornell Law Library*

- Goethe-Institut New York

- Ithaca College*

- National Digital Stewardship Residency Program

- Pratt Institute*

- Queens College, City University of New York*

- $\quad$ Syracuse University

- University at Buffalo, The State University of New York

\section{North Carolina}

- North Carolina State University

- University of North Carolina at Chapel Hill

- University of North Carolina at Greensboro

\section{Ohio}

- Hebrew Union College

- Kent State University

- Miami University-Ohio

- OCLC

- The Ohio State University

- College of Wooster*

\section{Pennsylvania}

- Swarthmore College

- Temple University

- Pennsylvania State University

- University of Pennsylvania

- University of Pittsburgh

\section{Tennessee}

- University of Tennessee

- Vanderbilt University

\section{Utah}

- University of Utah

\section{Virginia}

- Virginia Tech (Virginia Polytechnic Institute and State University)

\section{Washington}

- Western Washington University*

\section{West Virginia}

- West Virginia University

\section{Wisconsin}

- Marquette University

- University of Wisconsin at Madison 


\section{Notes}

1. American Library Association Board of Education for Librarianship, Annual Report (Chicago: American Library Association, 1925).

2. Julie Brewer, SPEC Kit 188: Internship, Residency, and Fellowship Programs in ARL Libraries (Washington, D.C.: Association of Research Libraries Office of Management Services, 1992), 67-70.

3. Teresa Y. Neely and Lorna Peterson, Achieving Racial and Ethnic Diversity among Academic and Research Librarians: The Recruitment, Retention, and Advancement of Librarians of Color: A White Paper by the ACRL Board of Directors Diversity Task Force, a Subgroup of the ACRL Board of Directors (Chicago: Association of College and Research Libraries, 2007).

4. Lorna Peterson, "Alternative Perspectives in Library and Information Science: Issues of Race," Journal of Education for Library and Information Science 37, no. 2 (1996): 163- -74.

5. Neely and Peterson, Achieving Racial and Ethnic Diversity, 10.

6. American Library Association, Office for Research and Statistics, "ALA Demographics Studies, March 2012," news release, March 2012, available online at www.ala.org/research/sites/ ala.org.research/files/content/March\%202012\%20report.pdf [accessed 21 October 2015].

7. Denise Adkins and Isabel Espinal, "The Diversity Mandate," Library Journal 129, no. 7 (2004): 52-54.

8. Ibid., 54 .

9. Denise M. Davis and Tracie D. Hall, Diversity Counts (Chicago: American Library Association, 2006), 3-38.

10. Ibid., 10.

11. Barbara I. Dewey and Jillian Keally, "Recruiting for Diversity: Strategies for 21st-Century Research Librarianship," Library Hi Tech 26, no. 4 (2008): 622-29.

12. Kelly McElroy and Chris Diaz, "Residency Programs and Demonstrating Commitment to Diversity," paper presented at the Biennial Meeting of the Association of College and Research Libraries, March 2015, Portland, Oregon.

13. Sandra L. Colby and Jennifer M. Ortman, Projections of the Size and Compositions of the U.S. Population 2014-2060, Current Population Reports (Washington, D.C.: U.S. Census Bureau, Population Division, 2014), available online at https://www.census.gov/content/dam/Census/library/ publications/2015/demo/p25-1143.pdf [accessed 21 October 2015].

14. Association for Library and Information Science Education, ALISE Statistical Report and Database 2011, available online at http://www.alise.org/statistical-reports-2 [accessed 19 January 2012].

15. Rebecca Hankins, Michele Saunders, and Ping Situ, "Diversity Initiatives vs. Residency Programs: Agents of Change?" College \& Research Libraries News 64, no. 5 (2003): 308-10, 315.

16. Cedric Herring, Cedric. "Does Diversity Pay? Race, Gender, and the Business Case for Diversity," American Sociological Review 74, no. 2 (2009): 208-24.

17. Taylor H. Cox and Stacy Blake, "Managing Cultural Diversity: Implications for Organizational Competitiveness," The Executive 5, no. 3 (1991): 45-56.

18. Gail Robinson and Kathleen Dechant, "Building a Business Case for Diversity," Academy of Management Executive 11, no. 3 (1997): 21-31.

19. Katherine W. Phillips, Katie A. Liljenquist, and Margaret A. Neale, "Is the Pain Worth the Gain? The Advantages and Liabilities of Agreeing with Socially Distinct Newcomers," Personality and Social Psychology Bulletin 35, no. 3 (2009): 336-50.

20. Ibid, 336.

21. Dewey and Keally, "Recruiting for Diversity," 629.

22. Julie Brewer, “Understanding the Organizational Value of Post-Master's Degree Residency Programs," Research Library Issues: A Bimonthly Report from ARL, CNI, and SPARC, no. 23 (2010): 23-27.

23. Ibid., 24.

24. Beverly P. Lynch, “Library Education: Its Past, Its Present, Its Future," Library Trends 56, no. 4 (2008): 931-53.

25. Ibid., 938.

26. World Encyclopedia of Library and Information Services, 3rd ed., s.v. "Williamson, Charles C." (Chicago: American Library Association, 1993).

27. Charles C. Williamson, Training for Library Service: A Report Prepared for the Carnegie Corporation of New York (New York: Carnegie Corporation, 1923).

28. World Encyclopedia of Library and Information, 863.

29. Francis R. St. John, Internship in the Library Profession: A Report Presented to the ALA Board of Education for Librarianship (Chicago: American Library Association, 1938).

30. Margo C. Trumpeter and Paul Gherman. "A Post-Master's Degree Internship Program," Library Journal 105, no. 12 (1980): 1366-69.

31. Julie Brewer, “Post-Master's Residency Programs: Enhancing the Development of New Professionals and Minority Recruitment in Academic and Research Libraries," College and Research Libraries 61, no. 6 (1997): 528-37. 
32. Ibid., 529.

33. Board of Education for Librarianship. The Preparation of Teacher-Librarians: A Report Based On Field Studies of Training Agencies for the ALA Board of Education for Librarianship (Chicago: American Library Association, 1937).

34. D. Lanier and C.L. Henderson. "Library Residencies and Internships as Indicators of Success: Evidence from Three Programs," Bulletin of the Medical Library Association 87, no. 2 (1999): 192.

35. OED Online, s.v. "affirmative action n." (Oxford University Press, September 2015), available online at www.oed.com/view/Entry/3424?rskey=xijySi\&result=1\&isAdvanced=false [accessed 21 October 2015].

36. UCI Office of Equal Opportunity and Diversity, "History of Affirmative Action" (last modified June 23, 2015), available online at www.oeod.uci.edu/aa.html [accessed 21 October 2015].

37. Joseph A. Boissé and Connie V. Dowell, "Increasing Minority Librarians in Academic Research Libraries," Library Journal 112 , no. 7 (1987): 52-54.

38. Drew DeSilver, "Supreme Court Says States Can Ban Affirmative Action; 8 Already Have," Pew Research Center, Apr. 22, 2014, available online at www.pewresearch.org/fact-tank/2014/04/22/ supreme-court-says-states-can-ban-affirmative-action-8-already-have/ [accessed 21 October 2015].

39. Julie Brewer, "Early Career Development and Post-Master's Residency Programs," in The New Graduate Experience: Post-MLS Residency Programs and Early Career Librarianship (Santa Barbara, Calif.: Libraries Unlimited, 2011), 3.

40. Trumpeter and Gherman, "A Post-Master's Degree Internship Program," 1368.

41. Ohio State University Libraries, "Mary P. Key Diversity Residency Program - Ohio State University Libraries" (last modified May 28, 2015), available online at http://library.osu.edu/ about/committees/diversity-and-inclusion/Mary-P-Key-Diversity-Residency-Program/ [accessed 21 October 2015].

42. Shannon Simpson, "Map of Library Residencies 2009-2010," ACRL Residency Interest Group (last modified Feb. 3, 2010), available online at http://acrl.ala.org/residency/?p=937 [accessed 21 October 2015].

43. Brewer, "Early Career Development and Post-Master's Residency Programs," 1.

44. Richard M. Dougherty and Wendy P. Lougee, "Research Library Residencies: ANew Model of Professional Development," Library Journal 108, no. 13 (1983): 1322-24.

45. William K. Black and Joan M. Leysen, "Fostering Success: The Socialization of Entry- level Librarians in ARL Libraries," Journal of Library Administration 36, no. 4 (2002): 3-27.

46. Ibid., 1.

47. William W. Sannwald, "Understanding Organizational Culture," Library Administration and Management 14, no. 1 (2000): 8-14.

48. Tomaro I. Taylor, "Changing the Faces of Librarianship: The Dr. Henrietta M. Smith Residency at USF," Florida Libraries 48, no. 2 (2005): 12-14.

49. Ibid., 13.

50. Peggy Johnson, "Retaining and Advancing Librarians of Color," College and Research Libraries 68 , no. 5 (2007): 405-17.

51. Ibid., 415.

52. Jason Kelly Alston, “Minerva's First Born: My Experiences as UNCG's First Diversity Resident Librarian," North Carolina Libraries 68, no. 1 (2010): 14-16.

53. Julie Brewer and Mark D. Winston, "Program Evaluation for Internship/Residency Programs in Academic and Research Libraries," College and Research Libraries 62, no. 4 (2001): 307-15.

54. U.S. Census Bureau, Population Division, "Population Profile of the United States, 2011" (last updated Sept. 7, 2011), available online at http://csrd.asu.edu/sites/default/files/pdf/Population $\% 20$ Profile $\% 20$ of $\% 20$ the $\% 20$ United \%20States.pdf [accessed 21 October 2015].

55. American Library Association, "Diversity Counts 2012" (last modified Feb. 3, 2010), available online at www.ala.org/offices/diversity/diversitycounts/divcounts [accessed 21 October 2015].

56. Barbara Stripling, "Equity, Diversity, and Inclusion: Standing Up for Our Values," American Libraries Magazine 45, no. 5 (2014): 5.

57. Kristin H. Gerhard and Jeanne M.K. Boydston, "A Library Committee on Diversity and Its Role in a Library Diversity Program," College and Research Libraries 54, no. 4 (1993): 335-43.

58. Kyung-Sun Kim and Sei-Ching Sin, "Increasing Ethnic Diversity in LIS: Strategies Suggested by Librarians of Color," Library Quarterly 78, no. 2 (2008): 153-77.

59. Ibid., 164.

60. U.S. Census Bureau, "About Race" (last modified July 8, 2013), available online at www. census.gov/topics/population/race/about.html [accessed 18 October 2015].

61. Carol T. Kulik and Loriann Roberson, "Diversity Initiative Effectiveness: What Organizations Can (and Cannot) Expect from Diversity Recruitment, Diversity Training, and Formal Mentoring Programs," in Diversity at Work (New York: Cambridge University Press, 2008), 265. 